\title{
Vibrational Spectra of Bis(dmit) Complexes of Main Group Metals: IR, Raman and $A b$ Initio Calculations
}

\author{
Glaucio B. Ferreira ${ }^{a}$, Nadia M. Comerlato ${ }^{a}$, James L. Wardell $^{a}$ and Eduardo Hollauer $^{*, b}$ \\ ${ }^{a}$ Instituto de Química, Universidade Federal do Rio de Janeiro, CP 68563, 21945-970 Rio de Janeiro - RJ, Brazil \\ ${ }^{b}$ Instituto de Química, Universidade Federal Fluminense, Outeiro de São João Batista s/n, Centro, \\ 24210-130 Niterói - RJ, Brazil
}

\begin{abstract}
Este trabalho apresenta uma investigação teórico-experimental dos espectros infravermelho/ Raman de diversos metais representativos coordenados com 1,3-ditiol-2-tiona-4,5-ditiolato (dmit), a saber $\left[\mathrm{NEt}_{4}\right]_{2}\left[\mathrm{Zn}\left(\mathrm{dmit}_{2}\right]\right.$, $\left[\mathrm{NEt}_{4}\right]\left[\mathrm{Sb}(\mathrm{dmit})_{2}\right]$ e $\left[\mathrm{NEt}_{4}\right]\left[\mathrm{Bi}(\mathrm{dmit})_{2}\right]$. Os espectros IV/Raman de todos os sólidos e também o espectro IV em solução do composto [ $\left.\mathrm{NEt}_{4}\right]_{2}\left[\mathrm{Zn}(\mathrm{dmit})_{2}\right]$ foram registrados de 4000 a $100 \mathrm{~cm}^{-1}$. Duas regiões foram claramente identificadas: abaixo de $380 \mathrm{~cm}^{-1}$ os modos apresentaram forte contribuição metal-ligante, e acima, os modos indicaram majoritária contribuição do ligante. Os espectros IV/Raman do $\mathrm{NEt}_{4} \mathrm{Br}$ também foram registrados. As bandas vibracionais foram atribuídas a partir da análise de compostos relacionados, de publicações prévias e comparadas com amplo conjunto de cálculos ab initio realizados com diversos ECPs (SBK, Sttutgart), conjunto de bases (com e sem funções d) e metodologias (RHF, DFT e MP2). As geometrias, freqüências e intensidades foram calculadas e comparadas com as freqüências experimentais visando atribuições seguras. Assim, uma excelente concordância foi obtida para diversas bandas experimentais.
\end{abstract}

This work reports a theoretical-experimental investigation of the infrared/Raman vibrational spectra of several metal 1,3-dithole-2-thione-4,5-dithiolate (dmit) complexes; [ $\left.\mathrm{NEt}_{4}\right]_{2}\left[\mathrm{Zn}(\mathrm{dmit})_{2}\right]$, $\left[\mathrm{NEt}_{4}\right]\left[\mathrm{Sb}(\mathrm{dmit})_{2}\right]$ and $\left[\mathrm{NEt}_{4}\right]\left[\mathrm{Bi}(\mathrm{dmit})_{2}\right]$. IR/Raman spectra of all the solids and the solution IR spectrum of $\left[\mathrm{NEt}_{4}\right]_{2}\left[\mathrm{Zn}(\mathrm{dmit})_{2}\right]$ were recorded from 4000 to $100 \mathrm{~cm}^{-1}$. Two regions were clearly identified: below $380 \mathrm{~cm}^{-1}$, the modes presented significant metal-ligand contributions, and above, the modes indicated major ligand contributions. IR/Raman spectra of $\mathrm{NEt}_{4} \mathrm{Br}$ have also been recorded. The vibrational bands have been assigned starting from the analysis of related compounds, of previous published spectra and compared to several ECPs (SBK, Stuttgart), basis sets (with and without functions d) and methodologies (RHF, MP2 and DFT). Geometries, frequencies and intensities were calculated and compared to the experimental frequencies seeking secure assignment. Thus, an excellent agreement was obtained for several experimental bands.

Keywords: IR, Raman, ab initio, RHF, DFT, MP2, dmit complexes, Zn, Sb, Bi

\section{Introduction}

The syntheses and properties of metal complexes with 1,2-dithiolato-polysulfido ligands have been intensely studied ${ }^{1-3}$ particularly since the discovery, by Cassoux and co-workers ${ }^{4}$ in 1986 , of the first metallic molecular superconductor, $[\mathrm{TTF}]\left[\mathrm{Ni}(\mathrm{dmit})_{2}\right]_{2}$, where dmit is the 1,3 dithiole-2-thione-4,5-dithiolate ligand. Presently dmit ligand complexes are the best studied.

The publication of Cassoux and co-workers ${ }^{4}$ seminal paper led a new impetus for the study of the applications

* e-mail: edu@kabir.gqt.uff.br<smiles>S=c1sc([S-])c([S-])s1</smiles>

of metal dmit compounds as super-conducting complexes, materials with non-linear optical properties and materials for electronic molecular devices. Such properties arise in part, from the rich redox chemistry of these compounds and the large polarizability of sulfur atoms.

An additional important feature for the super-conducting property on metal bis(dmit) complexes, such as $[\mathrm{TTF}]\left[\mathrm{Ni}(\mathrm{dmit})_{2}\right]_{2}$, is the planar geometry of the anions, ${ }^{3-5}$ 
which allows the formation of one and three-dimensional packing stacks in the solid state. However, a wide range of symmetries, coordination shells and solid state arrangements have been reported for $\left[\mathrm{M}(\mathrm{dmit})_{2}\right]^{\mathrm{y} / \mathrm{x}-}$ in ionic $[\mathrm{Q}]_{\mathrm{x}}\left[\mathrm{M}(\mathrm{dmit})_{2}\right]^{\mathrm{y} / \mathrm{x}}$ species [e.g., $\mathrm{Q}=$ onium cation] ${ }^{1-15}$ For instance, $\mathrm{D}_{2 \mathrm{~d}}$ symmetry is present in $\mathrm{Cu}$ (II) and $\mathrm{Zn}$ (II) complexes, $\mathrm{D}_{2 \mathrm{~h}}$ symmetry in $\mathrm{Ni}(\mathrm{II})$ complexes and $\mathrm{C}_{2}$ symmetry for complexes of the Group 15 elements, $\mathrm{Sb}$ and $\mathrm{Bi}$, in their trivalent oxidation state.

Despite the large volume of work on metal-dmit complexes, very few efforts have been devoted to the interpretation of their spectroscopic features. Actually most of the reported IR and Raman spectra have been used essentially for identification and characterization purposes. ${ }^{18-24}$ A full vibrational assignment of the IR and Raman spectra for most of the metal-dmit complexes is now required to assess features of the charge-transfer process and the superconductivity properties. Therefore we are presently starting a careful analysis of IR and Raman spectra concerning fundamental vibrational assignment, overtones, combination bands, and extensive ab initio calculations of all such properties. Such information is considered to be essential in providing a clear understanding of properties such as local symmetry and the crystal environment, inter and intra-molecular charge-transfer processes and its correlation to the molecular and crystalline vibration spectra.

The main goal of the work now reported was to study the vibrational spectra of the representative metal bis(dmit) complexes, $\left[\mathrm{NEt}_{4}\right]_{2}\left[\mathrm{Zn}(\mathrm{dmit})_{2}\right],\left[\mathrm{NEt}_{4}\right]\left[\mathrm{Sb}(\mathrm{dmit})_{2}\right]$ and $\left[\mathrm{NEt}_{4}\right]\left[\mathrm{Bi}(\mathrm{dmit})_{2}\right]$, and to provide a full assignment of their IR and Raman bands, assisted by ab initio calculations carried out with different effective core potentials, basis sets and calculation levels. Up to now, the only species previously studied with $a b$ initio calculations and Raman spectroscopy were $\mathrm{TTF}\left[\mathrm{Ni}(\mathrm{dmit})_{2}\right]_{2}, \mathrm{TTF}\left[\mathrm{Pd}(\mathrm{dmit})_{2}\right]_{2}$ and the neutral $\left[\mathrm{M}(\mathrm{dmit})_{2}\right](\mathrm{M}=\mathrm{Ni}, \mathrm{Pd}, \mathrm{Pt}) \cdot{ }^{20-22}$ A low resolution Raman spectrum of $\left[\mathrm{NEt}_{4}\right]_{2}\left[\mathrm{Zn}(\mathrm{dmit})_{2}\right]$ has been previously reported $;{ }^{24}$ however it suffered from sample decomposition in the laser beam.

The choice of bis(1,3-dithiole-2-thione-4,5-dithiolato)zincate, -antimonate and -bismuthate complexes presents a very convenient probe for family behaviour study. All the crystal structures of these complexes are known, ${ }^{6-15}$ including those of the tetraethylammonium salts, a family showing an increasing degree of inter-anion interactions from the $\mathrm{Zn}$ to Bi complex. Therefore we could assess M-S inter-anion interactions in the solid state, by carefully comparing the gas-phase calculation to the solid-state bulk spectra of these systems. The $\left[\mathrm{Zn}(\mathrm{dmit})_{2}\right]^{-2}$ anions in complex salts $[\mathrm{Q}]_{2}\left[\mathrm{Zn}(\mathrm{dmit})_{2}\right]\left(\mathrm{Q}=\mathrm{NEt}_{4}, \mathrm{NBu}_{4}\right.$, ferrocenyl$\mathrm{CH}_{2} \mathrm{NMe}_{3}, 1,4-\mathrm{Me}_{2}$-pyridinium, $\mathrm{PPh}_{4}$ and $\left.\mathrm{AsPh}_{4}\right)^{6-9}$ in the solid state, invariably have distorted tetrahedral geometries, and four coordinate zinc centres, with no anionanion interactions apart for very weak $\mathrm{S}$---S contacts close to its van der Waals radii sum. The distortion from an ideal zinc tetrahedral coordination is a consequence of the near $95^{\circ}$ bite angles of the chelating dmit ligands. Each dmit ligand is symmetrically coordinated, or nearly so, to zinc, with the $\mathrm{Zn}-\mathrm{S}$ bond lengths for all compounds falling in the narrow range of $2.3285(8)$ to $2.3522(10) \AA$. While the cation, $\mathrm{Q}$, has little or no effect on the zinc coordination geometry, the overall shape of the anion, and also the extent of the S---S contacts, do vary with $Q$.

The situation is different in the case of the anions in $[\mathrm{Q}]\left[\mathrm{M}(\mathrm{dmit})_{2}\right]\left(\mathrm{M}=\mathrm{Sb}^{10-12}\right.$ or $\left.\mathrm{Bi}^{13-15}\right)$ : here there are metalsulfur inter-anion interactions, that raise the coordination number of the metal to 6 , and that including the lone pair on the metal, provide highly distorted pseudo pentagonal bipyramidal geometries for $\mathrm{Sb}$ and $\mathrm{Bi}$. While the cation, $\mathrm{Q}^{+}$, in each of the series, influences the anion arrangements and also the very weak $\mathrm{S}$---S inter-anion interactions, the basic geometries about each of the two metals remain unaffected. The inter-anion M-S interactions, either with thiolato or thione $\mathrm{S}$ atoms, are considerably weaker than the intra-anion M-S bonds. As each of the dmit ligands is asymmetrically bound to the metal, three distinct regions of $\mathrm{M}-\mathrm{S}$ bond lengths are found. For [Q][Sb(dmit) $\left.)_{2}\right]\left(\mathrm{Q}=\mathrm{NEt}_{4}, \mathrm{PPh}_{4}\right.$ and $\left.\mathrm{AsPh}_{4}\right)$, the Sb-S bond lengths fall into the ranges: $2.4679(18)$ to $2.527(3)$, $2.6047(15)$ to 2.7311(6) [both intra anion bonds] and 3.271(4) to $3.5495(15) \AA$ [inter-anion bond]. For [Q][Bi(dmit) $\left.{ }_{2}\right](\mathrm{Q}=$ $\mathrm{NEt}_{4}, \mathrm{NBu}_{4}$ and $\left.\mathrm{Ph}_{4} \mathrm{As}\right)$, the $\mathrm{Bi}-\mathrm{S}$ bond lengths fall into three groups: $2.5872(10)$ to $2.527(3), 2.7299(11)$ to $2.87(1)$ [both intra bonds] and 3.0391(14) to 3.4628(13) [inter bonds]. Comparisons of the bond lengths suggest that the inter-anion interactions are relatively stronger for $\mathrm{Bi}$ than for $\mathrm{Sb}$.

\section{Experimental}

\section{Compounds}

The complexes $\left[\mathrm{NEt}_{4}\right]_{2}\left[\mathrm{Zn}(\mathrm{dmit})_{2}\right],{ }^{7}\left[\mathrm{NEt}_{4}\right]\left[\mathrm{Sb}(\mathrm{dmit})_{2}\right]^{12}$ and $\left[\mathrm{NEt}_{4}\right]\left[\mathrm{Bi}(\mathrm{dmit})_{2}\right]^{15}$ were obtained through well known published procedures. All complexes had physical properties, melting point and elemental analysis in agreement with the published values. A commercial sample of tetraethylammonium bromide was used as received.

\section{Ab initio calculations}

All calculations here presented have been designed to explore vibrational assignment of synthesized inorganic materials. Therefore the qualities sought in the calculations 
are robustness, reliability, facility to use, and economical, i.e., it must be executed on personal computers presently available. Therefore, it should employ ECPs with doublezeta basis function set easily available with RHF, DFT or, at most, MP2 methodologies.

Previous experiences showed that minimal basis provide unreliable frequencies and assignments while triple-zeta plus polarization led to intense geometry corrections but minor frequency switches when compared to our results. Considering the excessive costs and minor modifications we shall explore a compact easy-to-use ECP + double-zeta + polarization scheme along this work.

The calculations employed the programs GAMESS R5 ${ }^{25}$ on a Red Hat 7.3 Linux cluster and the Gaussian $98^{26}$ on a Window platform. The 6-31G basis set was employed for all elements except the central metallic atom. This basis set was chosen due to our previous experience with this basis set in several vibrational studies carried out in this group. ${ }^{33,34}$ This experience shows most frequencies regularly scaled by a factor of $0.8953 .{ }^{33}$ For the central metal atom, different basis set were tested. In the SBK calculation, the compact effective pseudopotential of Stevens et al. ${ }^{27}$ with double-zeta basis set was employed for the metal atom. We also applied this basis set extended with metal d functions (SBKd). In the Stuttgart ${ }^{28}$ pseudopotential/basis set, the electron core potential (ECP) from Stuttgart University was used.

Three alternative methods were studied: restricted Hartree-Fock calculations (RHF), Moller-Plessett perturbation theory of second order (MP2), and the functional density theory (DFT-B3LYP) by employing the B3 potential for the coulomb and LYP for the exchange correlation term. All calculations started with SCF convergence, geometry optimisation and after obtaining a stable minimum, the frequencies were calculated. This minimum was accepted as long as no imaginary molecular frequencies were detected. Once the normal modes were obtained, the IR and Raman intensities were evaluated. All modes were visually characterized through the graphical MOLDEN 3.7 and Molekel programs..$^{29,30}$

These calculations provide qualitative and quantitative consistent results for each of the three complexes. For this reason, only tables and figures related to the SBKd ECP/ basis set will be presented. However, whenever a significant difference is observed between the different ECPs, this will be indicated in the text.

\section{Vibrational spectra}

The infrared spectra, from 4000 to $150 \mathrm{~cm}^{-1}$, were recorded in CsI pellets using a Nicolet Magna-IR 760
Fourier transform instrument at room temperature, with a $4 \mathrm{~cm}^{-1}$ resolution. The FT-IR spectrum of $\left[\mathrm{NEt}_{4}\right]_{2}\left[\mathrm{Zn}(\mathrm{dmit})_{2}\right]$, from 4000 to $600 \mathrm{~cm}^{-1}$, was also recorded in dichloromethane solutions [concentrations: 5,2 and $0.5 \mathrm{~m} / \mathrm{v}$ ].

Raman spectra were obtained as powder in glass capillaries on a Nicolet FT Raman 950 spectrophotometer. The spectra were recorded at room temperature with a germanium detector, maintained at liquid nitrogen temperature and using $1064.0 \mathrm{~nm}$ radiation, generated by a Nd-YAG laser with a resolution of $2 \mathrm{~cm}^{-1}$. The samples were exposed to an average of 500 to $800 \mathrm{~mW}$ of laser intensity during the spectral recording.

\section{Results}

\section{$\left[\mathrm{Zn}(\text { dmit })_{2}\right]^{-2}$ geometry optimization}

The $\left[\mathrm{Zn}(\mathrm{dmit})_{2}\right]^{-2}$ anion, of $\mathrm{D}_{2 \mathrm{~d}}$ symmetry, has the highest symmetry found among the studied anions. The absence of significant interactions with neighbour dmit units should result in reduced environment effects in the IR and Raman spectra.

Figure 1 presents the $\left[\mathrm{Zn}(\mathrm{dmit})_{2}\right]^{-2}$ optimized structure and its atomic numbering scheme. Table 1 lists the main geometrical parameters obtained from the geometry optimization with the basis SBKd at RHF, DFT and MP2 level: no significant differences were found between the gas phase calculated values and those obtained in the crystal structure determination. Calculated parameters using the Stuttgart effective core potential were similar and hence are not displayed here. As the ligands share the same basis sets, any difference between these calculation procedures will result from the metal ECP and its basis set. Zn(II) has a filled $\mathrm{d}$ shell and provides its unoccupied $4 \mathrm{~s}$ and $4 \mathrm{p}$ orbitals for binding to the ligands. Therefore the most important electrons in the $\mathrm{Zn}-\mathrm{S}$ bonding must arise from the ligands.

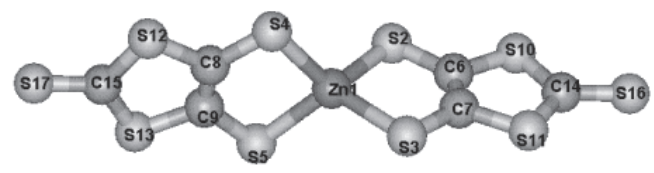

Figure 1. Three-dimensional representation of complex anion $\left[\mathrm{Zn}(\mathrm{dmit})_{2}\right]^{-2}$ calculated with ab initio method.

Calculations using the MP2 methodology provide $\mathrm{Zn}-\mathrm{S}$ bond lengths closest to those determined experimentally. Furthermore, intra-ligand bond lengths increase and the $\mathrm{Zn}-\mathrm{S}$ bond length decrease in going from the RHF to the MP2 and DFT calculations. This might be an indication that the main correlation energy process is related to the electronic delocalization from the dmit ligands toward the central metallic atom. 
Table 1. Main geometrical parameters for the complex anion $\left[\mathrm{Zn}(\mathrm{dmit})_{2}\right]^{-2}$ with ab initio calculations and the SBKd basis set

\begin{tabular}{lrrrr}
\hline & RHF & \multicolumn{1}{c}{ DFT } & MP2 & Exp. \\
\hline Bond $(\AA)$ & & & & \\
$\mathrm{S}^{16}=\mathrm{C}^{14}$ & 1.7055 & 1.7154 & 1.7274 & 1.6590 \\
$\mathrm{~S}^{11} \mathrm{C}^{14}$ & 1.7706 & 1.7995 & 1.8057 & 1.7210 \\
$\mathrm{~S}^{11}-\mathrm{C}^{7}$ & 1.8338 & 1.8499 & 1.8475 & 1.7520 \\
$\mathrm{~S}^{3}-\mathrm{C}^{7}$ & 1.8064 & 1.8035 & 1.8200 & 1.7415 \\
$\mathrm{C}^{6}=\mathrm{C}^{7}$ & 1.3285 & 1.3607 & 1.3730 & 1.3540 \\
$\mathrm{Zn}^{7} \mathrm{~S}^{3}$ & 2.4473 & 2.4251 & 2.3903 & 2.3503 \\
Bending $\left(^{o}\right)$ & & & & \\
$\mathrm{S}^{11} \mathrm{C}^{14} \mathrm{~S}^{16}$ & 123.8 & 124.2 & 124.0 & 123.7 \\
$\mathrm{C}^{7} \mathrm{~S}^{11} \mathrm{C}^{14}$ & 97.7 & 98.3 & 98.1 & 98.4 \\
$\mathrm{~S}^{11} \mathrm{C}^{7} \mathrm{C}^{6}$ & 116.1 & 115.8 & 115.9 & 115.3 \\
$\mathrm{ZnS}^{3} \mathrm{C}^{7}$ & 96.1 & 95.6 & 95.2 & 95.9 \\
$\mathrm{~S}^{2} \mathrm{ZnS} S^{3}$ & 118.6 & 117.7 & 116.6 & 115.9 \\
$\mathrm{~S}^{2} \mathrm{ZnS} S^{5}$ & 118.6 & 117.7 & 116.6 & 116.7 \\
$\mathrm{~S}^{2} \mathrm{ZnS} S^{4}$ & 118.6 & 117.7 & 116.6 & 119.4 \\
$\mathrm{~S}^{3} \mathrm{ZnS} S^{4}$ & 118.6 & 117.7 & 116.6 & 113.1 \\
Dihedral $\left({ }^{o}\right)$ & & & & \\
$\mathrm{ZnS}^{3} \mathrm{C}^{7} \mathrm{C}^{6}$ & 0.0 & 0.0 & 0.0 & 3.3 \\
$\mathrm{~S}^{3} \mathrm{C}^{7} \mathrm{~S}^{11} \mathrm{C}^{14}$ & 180.0 & 180.0 & 180.0 & 177.6 \\
$\mathrm{C}^{7} \mathrm{~S}^{11} \mathrm{C}^{14} \mathrm{~S}^{16}$ & 180.0 & 180.0 & 180.0 & 179.4 \\
\hline
\end{tabular}

\section{$\left[\mathrm{Zn}(\text { dmit })_{2}\right]^{-2}$ experimental frequencies}

All the IR/Raman peaks associated with the $\left[\mathrm{NEt}_{4}\right]^{+}$ cation were found in the spectra of the complex, $\left[\mathrm{NEt}_{4}\right]_{2}\left[\mathrm{Zn}(\mathrm{dmit})_{2}\right]$, see electronic supplementary information. The anion, $\left[\mathrm{Zn}(\mathrm{dmit})_{2}\right]^{-2}$, belongs to the $\mathrm{D}_{2 \mathrm{~d}}$ point group. By analyzing the molecular cartesian displacement representation and its irreducible composition, all genuine vibrations are given by: $\Gamma_{\text {vibration }}$ $=8 \mathrm{~A}_{1}+2 \mathrm{~A}_{2}+3 \mathrm{~B}_{1}+8 \mathrm{~B}_{2}+12 \mathrm{E}$. Therefore 45 vibrational modes are expected, from which 32 are infrared active $\left(\mathrm{B}_{2}\right.$ and $\mathrm{E})$ and 43 Raman active $\left(\mathrm{A}_{1}, \mathrm{~B}_{1}, \mathrm{~B}_{2}\right.$ and $\left.\mathrm{E}\right)$. A Raman spectrum of solid $\left[\mathrm{NEt}_{4}\right]_{2}\left[\mathrm{Zn}(\mathrm{dmit})_{2}\right]$ has been published. ${ }^{24}$ Unfortunately, the complex decomposed in the laser beam with a 10 to $800 \mathrm{~mW}$ output and the use of an indiumgallium-arsenic (InGaAs) detector only led to a low resolution spectrum. In our work, the use of a germanium detector and a lower laser intensity lead to a higher resolution spectrum, without decomposition.

The infrared absorption spectrum and the Raman scattering spectrum of solid $\left[\mathrm{NEt}_{4}\right]_{2}\left[\mathrm{Zn}(\mathrm{dmit})_{2}\right]$ are shown in Figures 2 and 3. Several main spectral features should be noted. The intense band at $1417 \mathrm{~cm}^{-1}$ was assigned by Cassoux $^{3}$ to the $\mathrm{C}=\mathrm{C}$ ligand stretching vibration. Between 1060 and $1010 \mathrm{~cm}^{-1}$, two very intense bands at 1059 and $1039 \mathrm{~cm}^{-1}$ were assigned as $\mathrm{C}=\mathrm{S}$ terminal stretching. These bands are generally used to confirm the presence of dmit ligands in complexes. ${ }^{7,8}$ Other assignments are: bands at 995 and $887 \mathrm{~cm}^{-1}$ to C-S stretches, the low intensity band at $524 \mathrm{~cm}^{-1}$, a breathing mode of the heterocycle dmit
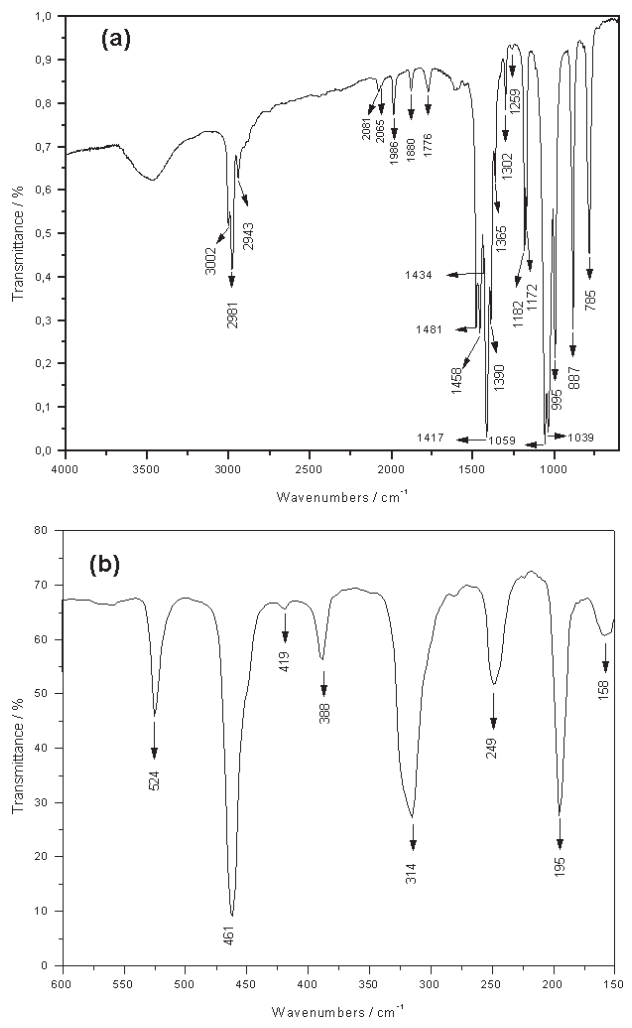

Figure 2. Infrared vibrational spectrum of the metal complex salt $\left[\mathrm{NEt}_{4}\right]_{2}\left[\mathrm{Zn}(\mathrm{dmit})_{2}\right]$ : (a) $4000-600$ and (b) $600-150 \mathrm{~cm}^{-1}$.
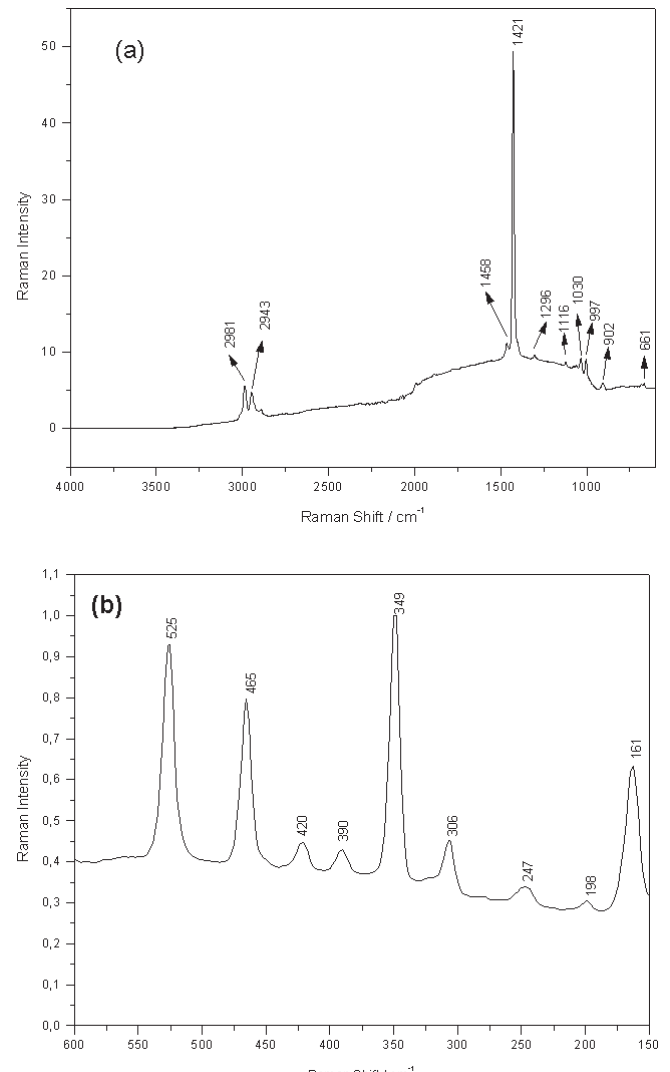

Figure 3. Vibrational Raman spectrum of the metal complex salt $\left[\mathrm{NEt}_{4}\right]_{2}\left[\mathrm{Zn}\left(\mathrm{dmit}_{2}\right]\right.$ : (a) 4000-600 and (b) $600-150 \mathrm{~cm}^{-1}$. 
complex, and the bands below $500 \mathrm{~cm}^{-1}$, to angular deformation and $\mathrm{Zn}-\mathrm{S}$ stretching modes.

Similar bands are found between 500 and $140 \mathrm{~cm}^{-1}$ in both the IR and the Raman spectra, e.g., the band at 524/ $525 \mathrm{~cm}^{-1}$, that is probably related to an $\mathrm{E}$ vibrational band. An intense band at $461 \mathrm{~cm}^{-1}$ with a low intensity shoulder at $450 \mathrm{~cm}^{-1}$ in the infrared spectrum corresponds to the single band at $465 \mathrm{~cm}^{-1}$ in the Raman spectrum. At $388 \mathrm{~cm}^{-1}$ (IR) and at $390 \mathrm{~cm}^{-1}$ (Raman), low intensity bands were observed. A band is observed at $349 \mathrm{~cm}^{-1}$ in the Raman spectrum. A central band is observed at $314 \mathrm{~cm}^{-1}$ in the IR spectrum, with shoulders at 322,306 and $300 \mathrm{~cm}^{-1}$, while in the Raman spectrum, only a single band at $306 \mathrm{~cm}^{-1}$ is observed. The bands at $249 \mathrm{~cm}^{-1}$ (IR) and 247 (Raman) have not been assigned. A very strong band at $195 \mathrm{~cm}^{-1}$ in the IR spectrum corresponds to the low intensity Raman band at $198 \mathrm{~cm}^{-1}$. Similarly, a weak IR band at $158 \mathrm{~cm}^{-1}$ corresponds to the strong band at $161 \mathrm{~cm}^{-1}$ in the Raman spectrum.

Several low intensity bands between 2100 and $1700 \mathrm{~cm}^{-1}$ in the IR have been assigned as overtone and combination bands, e.g., the 2065, 1986 and $1776 \mathrm{~cm}^{-1}$ bands have wavenumbers twice those at 1039, 995 and $888 \mathrm{~cm}^{-1}$, respectively. Furthermore, the 2081 and $1880 \mathrm{~cm}^{-1}$ can be considered as the combination of 1059, 1039 and $1417,461 \mathrm{~cm}^{-1}$ bands.

\section{$\left[\mathrm{Zn}(\text { dmit })_{2}\right]^{-2}$ frequency calculations}

Calculations have employed two different basis sets and ECPs (SBKd and Stuttgart) and three different methodological levels (RHF, DFT and MP2) for the vibration spectra calculation. Intensities were calculated for the infrared and Raman spectra. All frequencies showed real modes as expected for an equilibrium geometry. The results are presented on Table 2, where the following conventions should apply over all article: $v=$ stretching mode, $\sigma=$ scissoring mode, $\tau=$ twisting mode, $\omega=$ wagging mode, $\rho=$ rocking mode, $\phi=$ torsion, $\chi=$ out of plane.

The most noticeable observation concerns the constancy of the results with the different calculation methods. Even in the low frequency vibrational modes related to the $\mathrm{Zn}-\mathrm{S}$ stretching frequencies, the order and intensity of bands do not change either with the basis sets or with the methods. As expected, RHF calculated frequencies are greater than found experimentally, but with scaling factors smaller than those reported in the literature for most vibrations. ${ }^{33,34}$ An exception is the $\mathrm{C}=\mathrm{C}$ stretching frequency which was calculated to be $20 \%$ greater. For the low frequency modes, the results are remarkable, with most vibrations showing differences less than $1 \%$ of the experimental results. DFT and MP2 calculations overestimated most of the stretching vibrations, as expected, however in these cases the error was less than $7 \%$ for the DFT-B3LYP and 3\% for the MP2 method. Other frequencies showed a slight tendency to be under estimated.

It is remarkable that for all calculations, the same ordering of the vibrational modes was obtained, with the exceptions for the angular deformation $\omega\left(\mathrm{SC}_{\mathrm{t}} \mathrm{S}\right)$ out-ofplane at $515 \mathrm{~cm}^{-1}$ in the RHF and $445 \mathrm{~cm}^{-1}$ in the MP2 calculation and in the case of $\chi(\mathrm{SC}=\mathrm{CS})$ out-of-plane in the $\mathrm{C}=\mathrm{C}$ bond at $306 \mathrm{~cm}^{-1}$ in the RHF calculation. Such consistent ordering allowed the assignments of several bands not previously mentioned in the literature. Among these are the $\mathrm{Zn}-\mathrm{S}$ stretching modes at 314 and $306 \mathrm{~cm}^{-1}$, the $\mathrm{Zn}-\mathrm{S}$ stretching coupled to the $\sigma(\mathrm{SC}=\mathrm{S})$ bending at $248 \mathrm{~cm}^{-1}$ and the dmit bending around the zinc coordination at 195 and $158 \mathrm{~cm}^{-1}$, where the first mode was clearly assigned as asymmetric bending. Modes between 350 and $320 \mathrm{~cm}^{-1}$ were readily assigned to the ligand in-plane bending with a small metal participation. A mode of medium intensity, not previously assigned, was the dmit ring SC S bend at $461 \mathrm{~cm}^{-1}$, an useful mode for the dmit ring identification.

Between 1100 and $990 \mathrm{~cm}^{-1}$, the experimental spectra show three intense bands assigned as $\mathrm{C}=\mathrm{S}$ stretching modes. However, theoretical calculations show a pair of $a_{1} / b_{2}$ bands at $1057 / 1055 \mathrm{~cm}^{-1}$ and a pair of degenerate $e$ bands at $1038 \mathrm{~cm}^{-1}$ at RHF infrared spectrum.

According to previous studies, ${ }^{24}$ the assignment of these bands is not an easy task. A tentative assignment defines these three bands at 1059, 1039 and $995 \mathrm{~cm}^{-1}$ as $\mathrm{C}=\mathrm{S}$ stretch, C-S stretch and $\mathrm{SC}_{\mathrm{t}} \mathrm{S}$ angular deformation and an overtone of C-S stretch, respectively. ${ }^{24}$ Other possibility would be the first as $\mathrm{C}=\mathrm{S}$ stretch combined with SCS angular deformation, the second would be $\mathrm{C}=\mathrm{S}$ and $\mathrm{C}-\mathrm{S}$ stretch combined to the ring deformation, leaving the last unassigned. ${ }^{24}$ Another possibility would consider crystalline network splitting of the $e$ modes, not previously mentioned.

In order to explore the problem we recorded the infrared spectra in dichloromethane solution, which showed three bands with similar wavenumbers, with the central (1039 $\mathrm{cm}^{-1}$ ) being the most intense. The presence of similar bands in solution discards any suggestion of crystalline net effect in this multiplet. Therefore, we assign this band as an asymmetrical $\mathrm{C}=\mathrm{S}$ stretching while the other bands were assigned as symmetrical $\mathrm{C}=\mathrm{S}$ stretching and the $e$ C-S stretching modes. This assignment is consistent with a related unpublished work where we synthesized the corresponding dmio complex $(\mathrm{C}=\mathrm{S}$ changes to $\mathrm{C}=\mathrm{O}$ ), observing that bands at $1039 / 1059 \mathrm{~cm}^{-1}$ disappear. Therefore, based on intensity arguments, our final conclusion points to an symmetrical $\mathrm{C}=\mathrm{S}$ stretching at 
Table 2. Comparison between the observed and calculated wavenumbers $\left(\mathrm{cm}^{-1}\right)$ of vibrational spectra of $\left[\mathrm{NEt}_{4}\right]_{2}\left[\mathrm{Zn}\left(\mathrm{dmit}_{2}\right]\right.$

\begin{tabular}{|c|c|c|c|c|c|c|c|c|c|c|}
\hline \multicolumn{3}{|c|}{ RHF } & \multicolumn{2}{|c|}{ DFT } & \multicolumn{2}{|c|}{ MP2 } & \multirow[t]{2}{*}{ Symm. } & \multicolumn{2}{|c|}{ Exp. } & \multirow{2}{*}{$\begin{array}{l}\text { Mode } \\
\text { Assignment }\end{array}$} \\
\hline $\mathrm{cm}^{-1}$ & $\mathrm{I}_{\mathrm{IR}}$ & $\mathrm{I}_{\mathrm{RA}}$ & $\mathrm{cm}^{-1}$ & $\mathrm{I}_{\mathrm{IR}^{*}}$ & $\mathrm{~cm}^{-1}$ & $\mathrm{I}_{\mathrm{IR}}$ & & $\mathrm{IR}(\mathrm{s})$ & $\mathrm{R}(\mathrm{s})$ & \\
\hline 1732 & 0.00 & 213.60 & 1516 & 0 & 1457 & 0.00 & $\mathrm{~A}_{1}$ & & & $v(\mathrm{C}=\mathrm{C})$ \\
\hline 1732 & 2.54 & 11.72 & 1512 & 681 & 1455 & 13.45 & $\mathrm{~B}_{2}$ & 1417 & 1421 & $v(\mathrm{C}=\mathrm{C})$ \\
\hline 1057 & 0.00 & 26.14 & 1007 & 0 & 1021 & 0.00 & $\mathrm{~A}_{1}^{2}$ & 1059 & & $v(\mathrm{C}=\mathrm{S})$ \\
\hline 1055 & 23.02 & 0.09 & 1006 & 738 & 1016 & 27.81 & $\mathrm{~B}_{2}$ & 1039 & 1030 & $v(\mathrm{C}=\mathrm{S})$ \\
\hline 1038 & 0.04 & 0.00 & 928 & 11 & 950 & 0.25 & $\mathrm{E}$ & & & $v(\mathrm{Ce}-\mathrm{Sm})$ \\
\hline 1038 & 0.04 & 0.00 & 928 & 11 & 950 & 0.25 & $\mathrm{E}$ & & & $v(\mathrm{Ce}-\mathrm{Sm})$ \\
\hline 926 & 0.51 & 10.38 & 830 & 32 & 836 & 1.10 & $\mathrm{E}$ & 910 & 902 & $v(\mathrm{Ct}-\mathrm{Sa})$ \\
\hline 926 & 0.51 & 10.39 & 830 & 32 & 836 & 1.10 & $\mathrm{E}$ & & & $v(\mathrm{Ct}-\mathrm{Sa})$ \\
\hline 879 & 0.00 & 7.15 & 803 & 0 & 819 & 0.00 & $\mathrm{~A}_{1}$ & & & $v(\mathrm{Ce}-\mathrm{Sm})+v(\mathrm{Ce}-\mathrm{Sa})$ \\
\hline 878 & 2.76 & 1.63 & 801 & 221 & 817 & 1.96 & $\mathrm{~B}_{2}$ & 887 & & $v(\mathrm{Ce}-\mathrm{Sm})+v(\mathrm{Ce}-\mathrm{Sa})$ \\
\hline 765 & 0.01 & 0.16 & 700 & 1 & 714 & 0.10 & $\mathrm{E}^{2}$ & & & $v(\mathrm{Ce}-\mathrm{Sm})+v(\mathrm{Ce}-\mathrm{Sa})+v(\mathrm{Ct}-\mathrm{Sa})$ \\
\hline 765 & 0.01 & 0.15 & 700 & 1 & 714 & 0.10 & $\mathrm{E}$ & & & $v(\mathrm{Ce}-\mathrm{Sm})+v(\mathrm{Ce}-\mathrm{Sa})+v(\mathrm{Ct}-\mathrm{Sa})$ \\
\hline 644 & 0.00 & 4.53 & 528 & 0 & 512 & 0.00 & $\mathrm{~B}_{1}$ & & & $\tau(\mathrm{SC}=\mathrm{CS})$ \\
\hline 644 & 0.00 & 0.00 & 527 & 0 & 510 & 0.00 & $\mathrm{~A}_{2}$ & & & $\tau(\mathrm{SC}=\mathrm{CS})$ \\
\hline 537 & 0.00 & 16.38 & 494 & 0 & 497 & 0.00 & $\mathrm{~A}_{1}^{2}$ & & & $v(\mathrm{C}=\mathrm{S})+v(\mathrm{Ct}-\mathrm{S})$ \\
\hline 537 & 0.61 & 6.84 & 494 & 26 & 496 & 1.60 & $\mathrm{~B}_{2}$ & 524 & 525 & $v(\mathrm{C}=\mathrm{S})+v(\mathrm{Ct}-\mathrm{S})$ \\
\hline 474 & 0.00 & 6.13 & 439 & 0 & 438 & 0.00 & $\mathrm{~A}_{1}^{2}$ & & & $\sigma(\mathrm{SCtS})+v(\mathrm{Ce}-\mathrm{Sm})+v(\mathrm{Ce}-\mathrm{Sa})$ \\
\hline 474 & 1.75 & 6.00 & 438 & 89 & 435 & 3.05 & $\mathrm{~B}_{2}$ & 461 & 465 & $\sigma(\mathrm{SCtS})+v(\mathrm{Ce}-\mathrm{Sm})+v(\mathrm{Ce}-\mathrm{Sa})$ \\
\hline 515 & 0.00 & 0.68 & 436 & 2 & 445 & 0.10 & $\mathrm{E}$ & & & $\omega(\mathrm{SCtS})$ \\
\hline 515 & 0.00 & 0.68 & 436 & 2 & 445 & 0.10 & $\mathrm{E}$ & & & $\omega(\mathrm{SCtS})$ \\
\hline 411 & 0.06 & 8.63 & 375 & 4 & 381 & 0.07 & $\mathrm{E}$ & 388 & 390 & $\sigma(\mathrm{CCSm})+\rho(\mathrm{SCtS})$ \\
\hline 411 & 0.06 & 8.63 & 375 & 4 & 381 & 0.07 & $\mathrm{E}$ & & & $\sigma(\mathrm{CCSm})+\rho(\mathrm{SCtS})$ \\
\hline 350 & 0.00 & 0.58 & 329 & 2 & 333 & 0.25 & $\mathrm{~B}_{2}$ & & & $\sigma(\mathrm{CeSaCt})+\sigma(\mathrm{SCtS})$ \\
\hline 348 & 0.00 & 61.75 & 326 & 0 & 330 & 0.00 & $\mathrm{~A}_{1}^{2}$ & & 349 & $\sigma(\mathrm{CeSaCt})+\sigma(\mathrm{SCtS})$ \\
\hline 347 & 0.00 & 1.33 & 321 & 0 & 327 & 0.00 & $\mathrm{E}$ & & & $\sigma(\mathrm{CeSaCt})+\sigma(\mathrm{SC}=\mathrm{S})+v(\mathrm{Zn}-\mathrm{S})$ \\
\hline 347 & 0.00 & 1.20 & 321 & 0 & 327 & 0.00 & $\mathrm{E}$ & & & $\sigma(\mathrm{CeSaCt})+\sigma(\mathrm{SC}=\mathrm{S})+v(\mathrm{Zn}-\mathrm{S})$ \\
\hline 314 & 3.42 & 4.86 & 305 & 111 & 316 & 3.01 & $\mathrm{~B}_{2}$ & 314 & & $v(\mathrm{Zn}-\mathrm{S})$ \\
\hline 306 & 0.00 & 4.45 & 290 & 0 & 299 & 0.00 & $\mathrm{~A}_{1}^{2}$ & & 306 & $v(\mathrm{Zn}-\mathrm{S})$ \\
\hline 307 & 0.00 & 1.74 & 267 & 0 & 261 & 0.01 & $\mathrm{E}$ & & & $\chi(\mathrm{SC}=\mathrm{CS})$ \\
\hline 307 & 0.00 & 1.74 & 267 & 0 & 261 & 0.01 & $\mathrm{E}$ & & & $\chi(\mathrm{SC}=\mathrm{CS})$ \\
\hline 249 & 0.49 & 1.05 & 238 & 14 & 253 & 0.39 & $\mathrm{E}$ & 249 & 247 & $v(\mathrm{Zn}-\mathrm{S})+\sigma(\mathrm{SC}=\mathrm{S})$ \\
\hline 249 & 0.49 & 1.05 & 238 & 14 & 253 & 0.39 & $\mathrm{E}$ & & & $v(\mathrm{Zn}-\mathrm{S})+\sigma(\mathrm{SC}=\mathrm{S})$ \\
\hline 198 & 1.91 & 0.31 & 192 & 83 & 198 & 1.56 & $\mathrm{~B}_{2}$ & 195 & 198 & $\sigma(\mathrm{SZnS})$ \\
\hline 158 & 0.21 & 3.93 & 147 & 4 & 156 & 0.10 & $\mathrm{E}^{2}$ & 158 & 161 & $\omega(\mathrm{SZnS})+\sigma(\mathrm{SC}=\mathrm{S})$ \\
\hline 158 & 0.21 & 3.91 & 147 & 4 & 156 & 0.10 & $\mathrm{E}$ & & & $\omega(\mathrm{SZnS})+\sigma(\mathrm{SC}=\mathrm{S})$ \\
\hline 131 & 0.00 & 0.06 & 112 & 0 & 116 & 0.00 & $\mathrm{~B}_{1}$ & & & $\tau(\mathrm{SaCeSm})$ \\
\hline 130 & 0.00 & 0.00 & 111 & 0 & 114 & 0.00 & $\mathrm{~A}_{2}$ & & & $\tau(\mathrm{SaCeSm})$ \\
\hline 105 & 0.17 & 1.28 & 96 & 5 & 96 & 0.12 & $\mathrm{E}^{2}$ & & & $\omega(\mathrm{SZnS})+\tau(\mathrm{SaCeSm})$ \\
\hline 105 & 0.17 & 1.30 & 96 & 5 & 96 & 0.12 & $\mathrm{E}$ & & & $\omega(\mathrm{SZnS})+\tau(\mathrm{SaCeSm})$ \\
\hline 95 & 0.00 & 6.79 & 92 & 0 & 96 & 0.00 & $\mathrm{~A}_{1}$ & & & $\omega(\mathrm{SZnS})$ \\
\hline 74 & 0.00 & 3.39 & 70 & 0 & 74 & 0.00 & $\mathrm{E}$ & & & $\sigma(\mathrm{SZnS})+\chi(\mathrm{SC}=\mathrm{CS})+\sigma(\mathrm{SC}=\mathrm{S})$ \\
\hline 74 & 0.00 & 3.39 & 70 & 0 & 74 & 0.00 & $\mathrm{E}$ & & & $\sigma(\mathrm{SZnS})+\chi(\mathrm{SC}=\mathrm{CS})+\sigma(\mathrm{SC}=\mathrm{S})$ \\
\hline 42 & 0.00 & 9.21 & 32 & 0 & 39 & 0.00 & $\mathrm{~B}_{1}$ & & & $\sigma(\mathrm{SZnS})+\chi(\mathrm{SmCeSa})$ \\
\hline 16 & 0.00 & 0.04 & 14 & 0 & 13 & 0.00 & $\mathrm{E}$ & & & $\chi(\mathrm{SC}=\mathrm{CS})+\chi(\mathrm{SC}=\mathrm{S})+\sigma(\mathrm{SZnS})$ \\
\hline 16 & 0.00 & 3.41 & 14 & 0 & 13 & 0.00 & $\mathrm{E}$ & & & $\chi(\mathrm{SC}=\mathrm{CS})+\chi(\mathrm{SC}=\mathrm{S})+\sigma(\mathrm{SZnS})$ \\
\hline
\end{tabular}

${ }^{\text {a }}$ Calculated infrared intensities $\left(\mathrm{I}_{\mathrm{IR}}\right)$ are in $\operatorname{Debye}^{2}\left(\AA^{-2}\right.$-AMU). Raman scattering activities $\left(\mathrm{I}_{\mathrm{RA}}\right)$ are in $\AA^{4} \mathrm{AMU}{ }^{-1}$. Calculated infrared intensities $\left(\mathrm{I}_{\mathrm{IR}^{*}}\right)$ are in $\mathrm{KMmol}^{-1} \cdot{ }^{\mathrm{b}} \mathrm{Ce}=$ carbon ethylenic, $\mathrm{Ct}=$ carbon of thione, $\mathrm{Sm}=$ linked sulfur to the metal, $\mathrm{Sa}=$ sulfur of the ring.

$1059 \mathrm{~cm}^{-1}$, an asymmetrical $\mathrm{C}=\mathrm{S}$ stretching at $1039 \mathrm{~cm}^{-1}$ and a C-S stretching at $995 \mathrm{~cm}^{-1}$.

\section{$\left[\mathrm{Sb}(\text { dmit })_{2}\right]^{-1}$ geometry optimization}

The individual anion $\left[\mathrm{Sb}(\mathrm{dmit})_{2}\right]^{-1}$ in $\left[\mathrm{NEt}_{4}\right]\left[\mathrm{Sb}(\mathrm{dmit})_{2}\right]$ in the solid state has $\mathrm{C}_{2}$ symmetry. Figure 4 represents the optimised structure of the $\left[\mathrm{Sb}(\mathrm{dmit})_{2}\right]^{-1}$ and its atomic numbering scheme, while Table 3 lists the structural data obtained from the SBKd calculation using the three methods. All of which provided similar results, except for the dihedral angle SbSCC that presented a difference among the DFT method in comparison with the RHF and MP2 methods. The calculated optimised $\mathrm{C}_{2}$ gas phase structure is just the same as that found in the solid state, ignoring the inter-anionic Sb-S interactions: the gas-phase calculated and experimental solid state intra-atomic distances differed by less than $6 \%$. 
The results between the three basis functions do not exhibit significant variations as also found for the zincate complex discussed earlier, an indication that polarization functions do not play a qualitative role in this geometry calculation. Analysing the differences between the several calculations methods, it is noticeable that the RHF method provided the closest match to the experimental values, similarly as observed for the dmit zinc complex. The description of the correlation energy through the DFT or MP2 methods showed an increase on the Sb-S bonds.

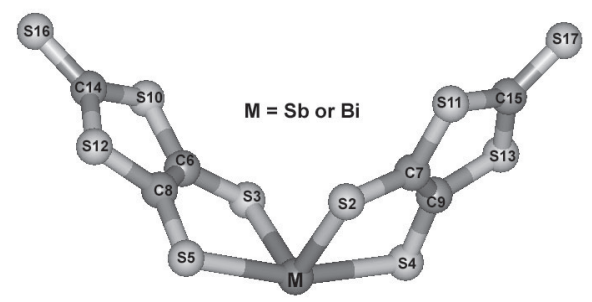

Figure 4. Three-dimensional representation of complex anions $\left.[\mathrm{M}(\mathrm{dmit})]_{2}\right]^{-1}(\mathrm{M}=\mathrm{Sb}$ or $\mathrm{Bi})$ calculated with ab initio method.

Table 3. Main geometrical parameters for the complex anion $\left[\mathrm{Sb}(\mathrm{dmit})_{2}\right]^{-1}$ with ab initio calculations and the SBKd basis set

\begin{tabular}{lrrrr}
\hline & RHF & DFT & MP2 & Exp. $^{7}$ \\
\hline Bond $(\AA)$ & & & & \\
$\mathrm{S}^{17}=\mathrm{C}^{15}$ & 1.6809 & 1.6917 & 1.7033 & 1.6800 \\
$\mathrm{~S}^{13}-\mathrm{C}^{15}$ & 1.7847 & 1.8122 & 1.8237 & 1.7250 \\
$\mathrm{~S}^{13} \mathrm{C}^{9}$ & 1.8219 & 1.8394 & 1.8420 & 1.7400 \\
$\mathrm{~S}^{4}-\mathrm{C}^{9}$ & 1.8052 & 1.8102 & 1.8243 & 1.7250 \\
$\mathrm{C}^{7}=\mathrm{C}^{9}$ & 1.3226 & 1.3513 & 1.3648 & 1.3800 \\
$\mathrm{Sb}-\mathrm{S}$ & 2.7215 & 2.7337 & 2.7345 & 2.6720 \\
& 2.5438 & 2.5808 & 2.5737 & 2.4960 \\
Bend $^{\left({ }^{o}\right)}$ & & & & \\
$\mathrm{S}^{13} \mathrm{C}^{15} \mathrm{~S}^{17}$ & 123.6 & 124.0 & 123.8 & 123.4 \\
$\mathrm{C}^{15} \mathrm{~S}^{13} \mathrm{C}^{9}$ & 96.7 & 97.2 & 96.9 & 97.7 \\
$\mathrm{~S}^{13} \mathrm{C}^{9} \mathrm{C}^{7}$ & 116.9 & 116.7 & 116.9 & 115.6 \\
$\mathrm{SbS}^{4} \mathrm{C}^{9}$ & 100.3 & 100.9 & 99.8 & 101.2 \\
$\mathrm{~S}^{2} \mathrm{SbS}^{4}$ & 82.8 & 83.2 & 83.7 & 83.2 \\
$\mathrm{~S}^{5} \mathrm{SbS}^{4}$ & 165.4 & 167.0 & 165.8 & 158.8 \\
$\mathrm{~S}^{5} \mathrm{SbS}^{2}$ & 88.0 & 88.9 & 87.4 & 83.5 \\
$\mathrm{~S}^{3} \mathrm{SbS}^{2}$ & 101.3 & 104.9 & 102.5 & 101.6 \\
Diedral $\left({ }^{\circ}\right)$ & & & & \\
SbS $^{4} \mathrm{C}^{7} \mathrm{C}^{9}$ & 13.3 & 8.9 & 14.6 & 8.1 \\
$\mathrm{~S}^{2} \mathrm{C}^{7} \mathrm{~S}^{11} \mathrm{C}^{15}$ & 178.7 & 178.8 & 178.3 & 174.5 \\
$\mathrm{C}^{7} \mathrm{~S}^{11} \mathrm{C}^{15} \mathrm{~S}^{17}$ & 178.8 & 178.7 & 178.8 & 174.9 \\
\hline
\end{tabular}

$\left[\mathrm{Sb}(\text { dmit })_{2}\right]^{-1}$ experimental frequencies

The molecular cartesian displacement reducible representation for $\mathrm{C}_{2}$ symmetry leads to the following genuine vibration space composition: $\Gamma_{\text {Vibration }}=23 \mathrm{~A}+$ 22B. All 45 expected vibrational modes are both infrared and Raman active.

We are not aware of any previous Raman spectra recorded for solid $[\mathrm{Q}]\left[\mathrm{Sb}(\mathrm{dmit})_{2}\right]$ complexes. The infrared and the Raman spectra, from 4000 to $150 \mathrm{~cm}^{-1}$, for the solid $\left[\mathrm{NEt}_{4}\right]_{2}\left[\mathrm{Sb}(\mathrm{dmit})_{2}\right]$, are shown in Figures 5 and 6. The strong band at $1435 \mathrm{~cm}^{-1}$ is assigned as the $\mathrm{C}=\mathrm{C}$ dmit stretch. Between 1060 and $1010 \mathrm{~cm}^{-1}$ two intense bands are assigned as $\mathrm{C}=\mathrm{S}$ stretches. These three bands, also present in the infrared/Raman spectra of $[\mathrm{Q}]_{2}\left[\mathrm{Zn}(\mathrm{dmit})_{2}\right]$, have been used to confirm the presence of the dmit group in such complexes..$^{10-12}$ The bands at 993,895 and $881 \mathrm{~cm}^{-1}$ are assigned as C-S stretches. At $524 \mathrm{~cm}^{-1}$, the breathing mode of the dmit ligant was observed.

It should be pointed out that no assignment of vibrational frequencies below $500 \mathrm{~cm}^{-1}$ has been previously made, even though a list of IR spectral bands was presented in a recent article. ${ }^{10}$ The infrared spectrum between 500 and $140 \mathrm{~cm}^{-1}$, showed eleven main bands, while the Raman presented just nine bands. Between 470 and $440 \mathrm{~cm}^{-1}$ in the infrared and Raman spectra, two bands are observed, an intense band at $461 \mathrm{~cm}^{-1}$ and a low intensity band at $445 \mathrm{~cm}^{-1}$. A low intensity band at $386 \mathrm{~cm}^{-1}$ is present in the IR spectrum, but not in the Raman spectrum. There are three bands at 351,336 and $328 \mathrm{~cm}^{-1}$ in the infrared spectrum: of these, the first two are Raman active as well. Between 300 and $260 \mathrm{~cm}^{-1}$, three infrared active bands were observed at 295,283 and $274 \mathrm{~cm}^{-1}$, of these the first and the last were also Raman active. The peak in the IR spectrum at $220 \mathrm{~cm}^{-1}$ and the shoulder at $226 \mathrm{~cm}^{-1}$ are matched in the Raman spectra by two distinct bands at 231 and $222 \mathrm{~cm}^{-1}$. At $150 \mathrm{~cm}^{-1}$, in the infrared and at $158 \mathrm{~cm}^{-1}$ on the Raman spectra a very intense band was observed.

Several low intensity bands have been assigned in this work as overtones and combination bands. Between 2100 and $1700 \mathrm{~cm}^{-1}$, not previously reported in the literature, we assign the bands at 2044, 1969 and $1757 \mathrm{~cm}^{-1}$ as overtones of the fundamental modes present at 1028, 993 and $881 \mathrm{~cm}^{-1}$. On the other hand, the bands at 2063, 1896 and $1782 \mathrm{~cm}^{-1}$ correspond to the combination of the respective fundamental modes at 1049,1028 and 1434, 463 and $895,881 \mathrm{~cm}^{-1}$. Clearly the low frequency region of the infrared and Raman spectra, from 360 to $150 \mathrm{~cm}^{-1}$, can be considered as a characteristic fingerprint region for metal-dmit complexes. The larger number of bands observed in this region for $\left[\mathrm{NEt}_{4}\right]\left[\mathrm{Sb}(\mathrm{dmit})_{2}\right]$ than for $\left[\mathrm{NEt}_{4}\right]_{2}\left[\mathrm{Zn}(\mathrm{dmit})_{2}\right]$, can be related to the reduced symmetry of the anion in $\left[\mathrm{NEt}_{4}\right]\left[\mathrm{Sb}(\mathrm{dmit})_{2}\right]\left(\mathrm{C}_{2}\right)$ compared to that in $\left[\mathrm{NEt}_{4}\right]_{2}\left[\mathrm{Zn}(\mathrm{dmit})_{2}\right]\left(\mathrm{D}_{2 \mathrm{~d}}\right)$.

\section{$\left[\mathrm{Sb}(\text { dmit })_{2}\right]^{-1}$ frequency calculations}

From the optimized geometries we carried out a hessian calculation and frequency evaluation of all vibrational modes of $\left[\mathrm{Sb}(\mathrm{dmit})_{2}\right]^{-1}$. All frequencies showed real modes, 

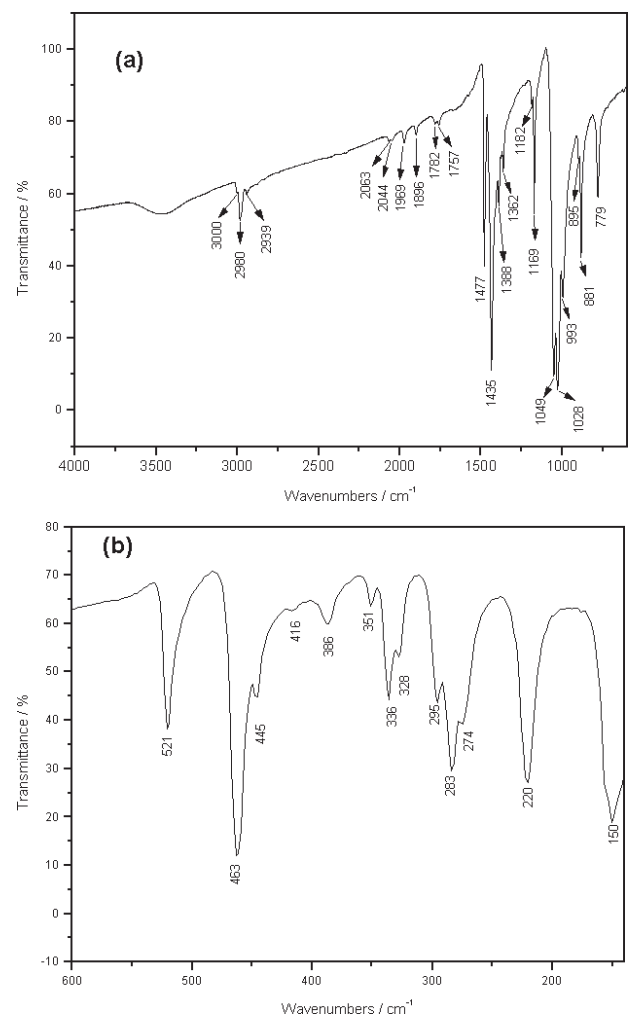

Figure 5. Infrared vibrational spectrum of the metal complex salt $\left[\mathrm{NEt}_{4}\right]\left[\mathrm{Sb}(\mathrm{dmit})_{2}\right]$ : (a) $4000-600$ and (b) $600-150 \mathrm{~cm}^{-1}$.
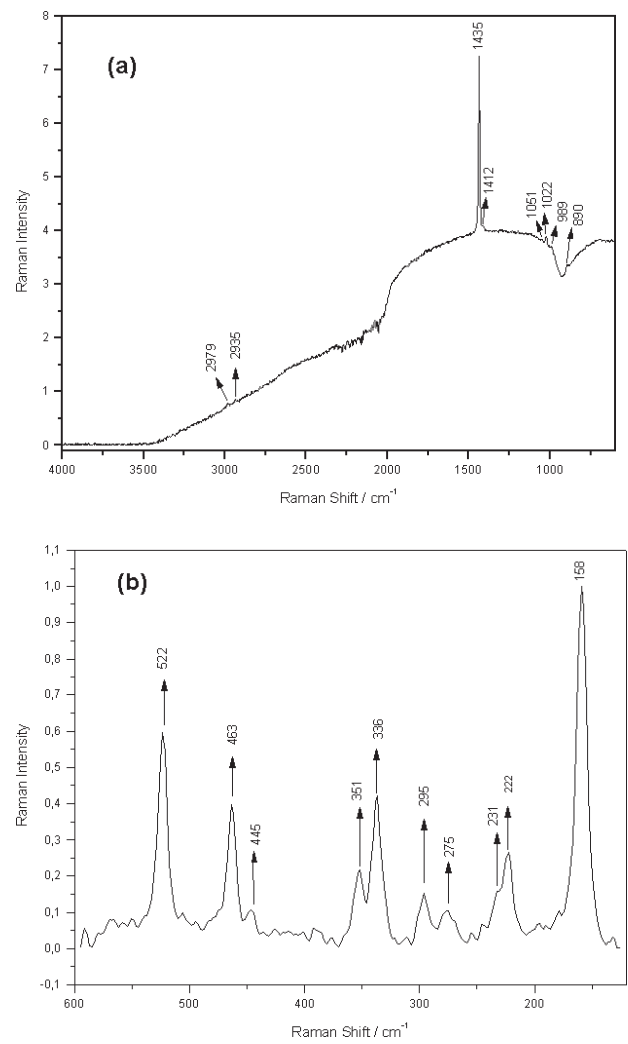

Figure 6. Vibrational Raman spectrum of the metal complex salt $\left[\mathrm{NEt}_{4}\right][\mathrm{Sb}$ (dmit) $]$ : (a) 4000-600 and (b) $600-150 \mathrm{~cm}^{-1}$. as expected for an equilibrium geometry. The frequencies and the corresponding intensities are shown in Table 4. As observed for the zinc complex, only minor differences between the various basis sets and the metallic ECP used were detected. Larger variations were observed between the different computational methods/electron correlation descriptions. For instance, the RHF results shown in Table 4 , clearly overestimated all frequencies, with the largest difference found for the $\mathrm{C}=\mathrm{C}$ stretch (20\%). Below 500 $\mathrm{cm}^{-1}$, most of the calculated frequencies were overestimated between 5 and $10 \%$. In the DFT and MP2 calculations, all deviations were found to be smaller, e.g., deviations for the $\mathrm{C}=\mathrm{C}$ stretch were $8 \%$ and $5 \%$ from DFT-B3LYP and MP2 methods respectively. For the other modes above 300 $\mathrm{cm}^{-1}$, most were overestimated between 1 to $10 \%$. However below $300 \mathrm{~cm}^{-1}$, much better agreement with experimental results were obtained, with discrepancies between 1 and $3 \%$. Remarkable is the prefect match between the frequency ordering found among all calculations carried out and the experimental results. Two exceptions, also observed for the zinc-dmit complex, should be pointed: $\mathrm{w}\left(\mathrm{SC}_{\mathrm{t}} \mathrm{S}\right)$ out-of-plane bending between 450 and $430 \mathrm{~cm}^{-1}$, for the DFT-B3LYP and MP2 methods. This reordering was not observed for the corresponding RHF calculation between 510 and $480 \mathrm{~cm}^{-1}$.

The calculations confirmed the assignments previously reported in the literature. ${ }^{10}$ The $\mathrm{C}=\mathrm{C}, \mathrm{C}=\mathrm{S}$ and $\mathrm{C}-\mathrm{S}$ stretches were recognized at 1435,1028 and $881 \mathrm{~cm}^{-1}$, respectively. The bands at 522 and $463 \mathrm{~cm}^{-1}$ were assigned as breathing mode from the dmit ring and $\mathrm{SC}_{\mathrm{t}} \mathrm{S}$ bending mode, respectively. Between 360 and $300 \mathrm{~cm}^{-1}$, a series of bands was assigned as $\mathrm{S}_{\mathrm{a}} \mathrm{C}_{\mathrm{e}} \mathrm{S}_{\mathrm{m}}$ bending mode slightly coupled to the $\mathrm{Sb}-\mathrm{S}$ stretching mode. The bands at 295 and $283 \mathrm{~cm}^{-1}$ were assigned as symmetrical and asymmetrical $\mathrm{Sb}-\mathrm{S}$ stretches coupled to $\mathrm{C}=\mathrm{C}$ out-of-plane twisting and $\mathrm{SC}=\mathrm{S}$ in-the-plane bending. These modes were assigned from their symmetry and spectroscopic activity. While the symmetric stretch is Raman-active, the asymmetrical stretch occurs in the infrared. The band at $274 \mathrm{~cm}^{-1}$ arises from the $\mathrm{C}=\mathrm{C}$ out-of-plane. The band at $222 \mathrm{~cm}^{-1}$ results from the $\mathrm{Sb}-\mathrm{S}$ stretching coupled to the $\mathrm{S}=\mathrm{C}_{\mathrm{t}} \mathrm{S}$ bending. Finally the $150 \mathrm{~cm}^{-1}$ band was assigned as the fivemembers-ring deformation formed by the metal coordination to the thiolate sulfur.

\section{$\left.[\text { Bi(dmit })_{2}\right]^{-1}$ geometry optimizations}

The symmetry of the $\left[\mathrm{Bi}(\mathrm{dmit})_{2}\right]^{-1}$ anion in $\left[\mathrm{NEt}_{4}\right]\left[\mathrm{Bi}(\mathrm{dmit})_{2}\right]$ is $\mathrm{C}_{2}$. Table 5 lists the results for the geometry optimization carried out with the SBKd basis set and ECP pseudopotential. As previously mentioned 
Table 4. Comparison between the observed and calculated wavenumbers $\left(\mathrm{cm}^{-1}\right)$ of vibrational spectra of $\left[\mathrm{NEt}_{4}\right]\left[\mathrm{Sb}\left(\mathrm{dmit}_{2}\right]\right.$

\begin{tabular}{|c|c|c|c|c|c|c|c|c|c|c|}
\hline \multicolumn{3}{|c|}{ RHF } & \multicolumn{2}{|c|}{ DFT } & \multicolumn{2}{|c|}{ MP2 } & \multirow[t]{2}{*}{ Symm. } & \multicolumn{2}{|c|}{ Exp. } & \multirow{2}{*}{$\begin{array}{l}\text { Mode } \\
\text { Assignment }\end{array}$} \\
\hline $\mathrm{cm}^{-1}$ & $\mathrm{I}_{\mathrm{IR}}$ & $\mathrm{I}_{\mathrm{RA}}$ & $\mathrm{cm}^{-1}$ & $\mathrm{I}_{\mathrm{IR}^{*}}$ & $\mathrm{~cm}^{-1}$ & $\mathrm{I}_{\mathrm{IR}}$ & & $\mathrm{IR}(\mathrm{s})$ & $\mathrm{R}(\mathrm{s})$ & \\
\hline 1774 & 0.96 & 17.38 & 1560 & 111 & 1511 & 2.38 & B & 1435 & 1435 & $v(\mathrm{C}=\mathrm{C})$ \\
\hline 1774 & 0.35 & 50.51 & 1560 & 34 & 1510 & 1.08 & A & & & $v(\mathrm{C}=\mathrm{C})$ \\
\hline 1090 & 10.34 & 0.68 & 1036 & 238 & 1052 & 8.71 & A & 1049 & & $v(\mathrm{C}=\mathrm{S})$ \\
\hline 1088 & 13.88 & 0.48 & 1034 & 564 & 1050 & 12.39 & $\mathrm{~B}$ & 1028 & 1022 & $v(\mathrm{C}=\mathrm{S})$ \\
\hline 1068 & 0.01 & 3.28 & 938 & 4 & 956 & 0.12 & A & 993 & 989 & $v(\mathrm{Ce}-\mathrm{Sm})$ \\
\hline 1068 & 0.00 & 4.24 & 937 & 4 & 956 & 0.08 & $\mathrm{~B}$ & & & $v(\mathrm{Ce}-\mathrm{Sm})$ \\
\hline 917 & 0.01 & 23.00 & 819 & 29 & 832 & 0.64 & A & & & $v(\mathrm{Ct}-\mathrm{Sa})$ \\
\hline 917 & 0.83 & 3.85 & 816 & 50 & 830 & 1.22 & B & 895 & 890 & $v(\mathrm{Ct}-\mathrm{Sa})$ \\
\hline 915 & 0.84 & 21.79 & 816 & 103 & 814 & 0.09 & A & & & $v(\mathrm{Ce}-\mathrm{Sm})+v(\mathrm{Ce}-\mathrm{Sa})$ \\
\hline 913 & 1.11 & 15.68 & 815 & 14 & 813 & 0.78 & $\mathrm{~B}$ & 881 & & $v(\mathrm{Ce}-\mathrm{Sm})+v(\mathrm{Ce}-\mathrm{Sa})$ \\
\hline 794 & 0.05 & 5.64 & 712 & 3 & 718 & 0.09 & A & & & $v(\mathrm{Ce}-\mathrm{Sm})+v(\mathrm{Ce}-\mathrm{Sa})+v(\mathrm{Ct}-\mathrm{Sa})$ \\
\hline 793 & 0.20 & 1.02 & 712 & 12 & 718 & 0.53 & $\mathrm{~B}$ & & & $v(\mathrm{Ce}-\mathrm{Sm})+v(\mathrm{Ce}-\mathrm{Sa})+v(\mathrm{Ct}-\mathrm{Sa})$ \\
\hline 654 & 0.00 & 0.90 & 540 & 0 & 529 & 0.00 & A & & & $\tau(\mathrm{SC}=\mathrm{CS})$ \\
\hline 652 & 0.01 & 0.73 & 539 & 0 & 527 & 0.00 & B & & & $\tau(\mathrm{SC}=\mathrm{CS})$ \\
\hline 526 & 0.32 & 22.06 & 482 & 13 & 476 & 0.87 & A & & & $v(\mathrm{C}=\mathrm{S})+v(\mathrm{Ct}-\mathrm{S})$ \\
\hline 526 & 0.42 & 4.92 & 481 & 32 & 475 & 1.19 & $\mathrm{~B}$ & 522 & 522 & $v(\mathrm{C}=\mathrm{S})+v(\mathrm{Ct}-\mathrm{S})$ \\
\hline 487 & 0.59 & 9.26 & 446 & 11 & 445 & 0.44 & $\mathrm{~A}$ & & & $\sigma(\mathrm{SCtS})+v(\mathrm{Ce}-\mathrm{Sm})+v(\mathrm{Ce}-\mathrm{Sa})$ \\
\hline 486 & 1.24 & 3.92 & 446 & 23 & 444 & 0.23 & $\mathrm{~B}$ & 463 & 463 & $\sigma(\mathrm{SCtS})+v(\mathrm{Ce}-\mathrm{Sm})+v(\mathrm{Ce}-\mathrm{Sa})$ \\
\hline 509 & 0.00 & 0.57 & 444 & 0 & 443 & 0.03 & A & & & $\omega(\mathrm{SCtS})$ \\
\hline 509 & 0.01 & 4.43 & 444 & 16 & 443 & 0.81 & $\mathrm{~B}$ & 445 & 445 & $\omega(\mathrm{SCtS})$ \\
\hline 419 & 0.04 & 7.09 & 380 & 1 & 384 & 0.03 & $\mathrm{~A}$ & & & $\sigma(\mathrm{CCSm})+\rho(\mathrm{SCtS})$ \\
\hline 417 & 0.06 & 5.32 & 379 & 3 & 382 & 0.05 & $\mathrm{~B}$ & 386 & & $\sigma(\mathrm{CCSm})+\rho(\mathrm{SCtS})$ \\
\hline 379 & 0.12 & 12.83 & 336 & 8 & 339 & 0.06 & A & 351 & 351 & $\sigma(\mathrm{CeSaCt})+\sigma(\mathrm{SCtS})+v(\mathrm{Sb}-\mathrm{S})$ \\
\hline 375 & 0.35 & 2.20 & 335 & 1 & 338 & 0.24 & $\mathrm{~B}$ & & & $\sigma(\mathrm{CeSaCt})+\sigma(\mathrm{SCtS})+v(\mathrm{Sb}-\mathrm{S})$ \\
\hline 360 & 0.02 & 22.18 & 331 & 1 & 332 & 0.00 & $\mathrm{~A}$ & 336 & 336 & $\sigma(\mathrm{CeSaCt})+v(\mathrm{Sb}-\mathrm{S})$ \\
\hline 358 & 0.05 & 13.42 & 325 & 3 & 328 & 0.01 & $\mathrm{~B}$ & 328 & & $\sigma(\mathrm{CeSaCt})+v(\mathrm{Sb}-\mathrm{S})$ \\
\hline 330 & 0.28 & 28.42 & 296 & 8 & 298 & 0.25 & A & 295 & 295 & $v(\mathrm{Sb}-\mathrm{S})+\chi(\mathrm{SC}=\mathrm{CS})+\sigma(\mathrm{SC}=\mathrm{S})$ \\
\hline 326 & 1.31 & 2.92 & 288 & 109 & 291 & 2.21 & $\mathrm{~B}$ & 283 & & $v(\mathrm{Sb}-\mathrm{S})+\chi(\mathrm{SC}=\mathrm{CS})+\sigma(\mathrm{SC}=\mathrm{S})$ \\
\hline 304 & 0.65 & 9.70 & 270 & 16 & 265 & 0.08 & $\mathrm{~B}$ & 274 & 275 & $\chi(\mathrm{SC}=\mathrm{CS})+v(\mathrm{Sb}-\mathrm{S})$ \\
\hline 303 & 0.08 & 12.85 & 266 & 0 & 258 & 0.01 & A & & & $\chi(\mathrm{SC}=\mathrm{CS})+v(\mathrm{Sb}-\mathrm{S})$ \\
\hline 255 & 0.00 & 32.88 & 230 & 0 & 235 & 0.00 & $\mathrm{~A}$ & & 231 & $v(\mathrm{Sb}-\mathrm{S})+\sigma(\mathrm{SC}=\mathrm{S})$ \\
\hline 245 & 2.46 & 0.45 & 232 & 61 & 236 & 2.08 & $\mathrm{~B}$ & 222 & & $v(\mathrm{Sb}-\mathrm{S})+\sigma(\mathrm{SC}=\mathrm{S})$ \\
\hline 168 & 2.14 & 10.90 & 152 & 6 & 158 & 0.17 & $\mathrm{~A}$ & & 158 & $\sigma(\mathrm{SSbS})$ \\
\hline 176 & 0.25 & 10.06 & 158 & 78 & 158 & 1.84 & $\mathrm{~B}$ & 150 & & $\sigma(\mathrm{SSbS})$ \\
\hline 152 & 1.34 & 1.87 & 142 & 5 & 146 & 0.10 & $\mathrm{~B}$ & & & $\sigma(\mathrm{SSbS})+\mathrm{w}(\mathrm{SC}=\mathrm{S})$ \\
\hline 158 & 0.01 & 8.00 & 131 & 0 & 143 & 0.01 & $\mathrm{~A}$ & & & $\tau(\mathrm{SmCeSa})$ \\
\hline 134 & 0.04 & 0.24 & 113 & 0 & 115 & 0.02 & $\mathrm{~B}$ & & & $\tau(\mathrm{SmCeSa})$ \\
\hline 125 & 0.02 & 11.69 & 112 & 0 & 110 & 0.01 & A & & & $\tau(\mathrm{SSbS})+\tau(\mathrm{SmCeSa})$ \\
\hline 118 & 0.08 & 5.62 & 98 & 3 & 103 & 0.06 & A & & & $\omega(\mathrm{SSbS})+\tau(\mathrm{SmCeSa})$ \\
\hline 98 & 0.11 & 2.51 & 92 & 3 & 89 & 0.07 & $\mathrm{~B}$ & & & $\omega(\mathrm{SSbS})+\tau(\mathrm{SC}=\mathrm{S})$ \\
\hline 77 & 0.01 & 4.06 & 66 & 0 & 66 & 0.00 & A & & & $\omega(\mathrm{SSbS})+\chi(\mathrm{SC}=\mathrm{CS})+\tau(\mathrm{SC}=\mathrm{S})$ \\
\hline 61 & 0.01 & 2.63 & 50 & 0 & 50 & 0.00 & $\mathrm{~B}$ & & & $\tau(\mathrm{SSbS})+\chi(\mathrm{SmCeSa})$ \\
\hline 53 & 0.00 & 7.72 & 42 & 0 & 45 & 0.00 & A & & & $\chi(\mathrm{SmCeSa})$ \\
\hline 30 & 0.00 & 2.35 & 26 & 0 & 25 & 0.00 & $\mathrm{~B}$ & & & $\sigma(\mathrm{SSbS})+\chi(\mathrm{SmCeSaCt})$ \\
\hline 13 & 0.01 & 1.30 & 12 & 0 & 11 & 0.00 & $\mathrm{~A}$ & & & $\sigma(\mathrm{SSbS})+\chi(\mathrm{SmCCSa})$ \\
\hline
\end{tabular}

${ }^{a}$ Calculated infrared intensities $\left(I_{I R}\right)$ are in Debye ${ }^{2}\left(\AA^{-2}-A M U\right)$. Raman scattering activities $\left(I_{R A}\right)$ are in $\AA^{4} A M U^{-1}$. Calculated infrared intensities $\left(\mathrm{I}_{\mathrm{IR}}\right)$ are in $\mathrm{KMmol}^{-1} \cdot{ }^{\mathrm{b}} \mathrm{Ce}=$ carbon ethylenic, $\mathrm{Ct}=$ carbon of thione, $\mathrm{Sm}=$ linked sulfur to the metal, $\mathrm{Sa}=$ sulfur of the ring.

for the zinc and antimony systems, only minor differences have been found between the calculations using the main geometrical optimized parameters with other basis sets and ECP. Therefore these results will be not presented. Similarly as found for zinc and antimony, most of the calculated geometrical parameters for the isolated anion in the gas phase showed small differences compared to those obtained in the X-ray diffraction study: differences were less than $6 \%$ for bond lengths and $10 \%$ for the angle between the ligand planes and the dihedral angle, BiSCC. This last angle difference is considered to result from the strong inter-anionic interactions occurring in the crystalline environment, and which were neglected in the gas phase calculations. As previously noted, the RHF method provided the best match to the experimental geometrical parameters. The correlation energy description through DFT and MP2 methods improved the Bi-S bond lengths in the $\left[\mathrm{NEt}_{4}\right]\left[\mathrm{Bi}(\mathrm{dmit})_{2}\right]$ complex. 
Table 5. Main geometrical parameters for the complex anion $\left[\mathrm{Bi}(\mathrm{dmit})_{2}\right]^{-1}$ with ab initio calculations and the SBKd basis set

\begin{tabular}{lrrrr}
\hline & RHF & DFT & MP2 & Exp. \\
\hline Bond $(\AA)$ & & & & \\
$\mathrm{S}^{17}=\mathrm{C}^{15}$ & 1.6816 & 1.6919 & 1.7035 & 1.6455 \\
$\mathrm{~S}^{13} \mathrm{C}^{15}$ & 1.7834 & 1.8110 & 1.8225 & 1.7231 \\
$\mathrm{~S}^{13}-\mathrm{C}^{9}$ & 1.8244 & 1.8425 & 1.8452 & 1.7493 \\
$\mathrm{~S}^{4}-\mathrm{C}^{9}$ & 1.8069 & 1.8099 & 1.8248 & 1.7327 \\
$\mathrm{C}^{7}=\mathrm{C}^{9}$ & 1.3233 & 1.3527 & 1.3658 & 1.3402 \\
$\mathrm{Bi}^{-\mathrm{S}}$ & 2.7861 & 2.7991 & 2.8053 & 2.8339 \\
& 2.6012 & 2.6565 & 2.6520 & 2.6668 \\
Bend $\left.^{o}\right)$ & & & & \\
$\mathrm{S}^{13} \mathrm{C}^{15} \mathrm{~S}^{17}$ & 123.7 & 124.0 & 123.9 & 124.4 \\
$\mathrm{C}^{15} \mathrm{~S}^{13} \mathrm{C}^{9}$ & 96.9 & 97.4 & 97.1 & 99.2 \\
$\mathrm{~S}^{13} \mathrm{C}^{9} \mathrm{C}^{7}$ & 116.8 & 116.6 & 116.7 & 115.1 \\
$\mathrm{BiS}^{4} \mathrm{C}^{9}$ & 100.5 & 100.9 & 100.3 & 96.9 \\
$\mathrm{~S}^{2} \mathrm{BiS}^{4}$ & 81.9 & 81.8 & 82.5 & 76.5 \\
$\mathrm{~S}^{5} \mathrm{BiS}^{4}$ & 166.8 & 169.2 & 167.1 & 152.5 \\
$\mathrm{~S}^{5} \mathrm{BiS}^{2}$ & 89.8 & 91.8 & 89.7 & 84.2 \\
$\mathrm{~S}^{3} \mathrm{BiS}^{2}$ & 101.9 & 108.0 & 105.7 & 89.6 \\
Dihedral $^{o}\left(^{\circ}\right.$ & & & & \\
$\mathrm{BiS}^{2} \mathrm{C}^{7} \mathrm{C}^{9}$ & 9.7 & 5.9 & 9.2 & 30.3 \\
$\mathrm{~S}^{2} \mathrm{C}^{7} \mathrm{~S}^{11} \mathrm{C}^{15}$ & 179.4 & 179.5 & 179.3 & 177.4 \\
$\mathrm{C}^{7} \mathrm{~S}^{11} \mathrm{C}^{15} \mathrm{~S}^{17}$ & 179.1 & 178.9 & 178.9 & 177.6 \\
\hline & & & &
\end{tabular}

\section{$\left.[\text { Bi(dmit })_{2}\right]^{-1}$ experimental frequencies}

The $\left[\mathrm{Bi}(\mathrm{dmit})_{2}\right]^{-1}$ and $\left[\mathrm{Sb}(\mathrm{dmit})_{2}\right]^{-1}$ structures have the same symmetry and both exhibit 45 vibrational infrared and Raman active modes. The infrared and Raman spectra of solid $\left[\mathrm{NEt}_{4}\right]\left[\mathrm{Bi}(\mathrm{dmit})_{2}\right]$, from 4000 to $120 \mathrm{~cm}^{-1}$, are shown in Figures 7 and 8.

The intense band at $1421 \mathrm{~cm}^{-1}$ was assigned to the $\mathrm{C}=\mathrm{C}$ stretch $\cdot{ }^{14}$ Two other very strong bands, 1057 and 1022 $\mathrm{cm}^{-1}$, have been assigned as symmetrical and asymmetric $\mathrm{C}=\mathrm{S}$ stretches. A band at $883 \mathrm{~cm}^{-1}$ and a shoulder at 997 $\mathrm{cm}^{-1}$ were assigned as C-S stretches. At 534 and $518 \mathrm{~cm}^{-1}$, two other bands have been assigned as dmit ring breathing modes.

Six high intensity bands occur in the infrared spectrum between 500 and $140 \mathrm{~cm}^{-1}$, while seven high intensity bands were detected in the Raman spectrum. In the region from 470 to $440 \mathrm{~cm}^{-1}$, in both the infrared and Raman spectra, an intense band at $463 \mathrm{~cm}^{-1}$ and a shoulder at 447 $\mathrm{cm}^{-1}$ are found. Following these bands, a central and more intense band at $386 \mathrm{~cm}^{-1}$ and two weak bands at 397 and $376 \mathrm{~cm}^{-1}$ are observed. In the Raman spectrum a single band was identified at $389 \mathrm{~cm}^{-1}$. Three bands were observed at 350,331 and $328 \mathrm{~cm}^{-1}$ in the infrared spectrum, but only the first was actually observed in Raman spectrum. Between 320 and $300 \mathrm{~cm}^{-1}$, a shoulder at $310 \mathrm{~cm}^{-1}$ and a band at $302 \mathrm{~cm}^{-1}$ are observed in infrared spectrum. In the Raman spectrum, the main band in this region was observed at $310 \mathrm{~cm}^{-1}$ with a shoulder at $302 \mathrm{~cm}^{-1}$. At $279 \mathrm{~cm}^{-1}$ in the
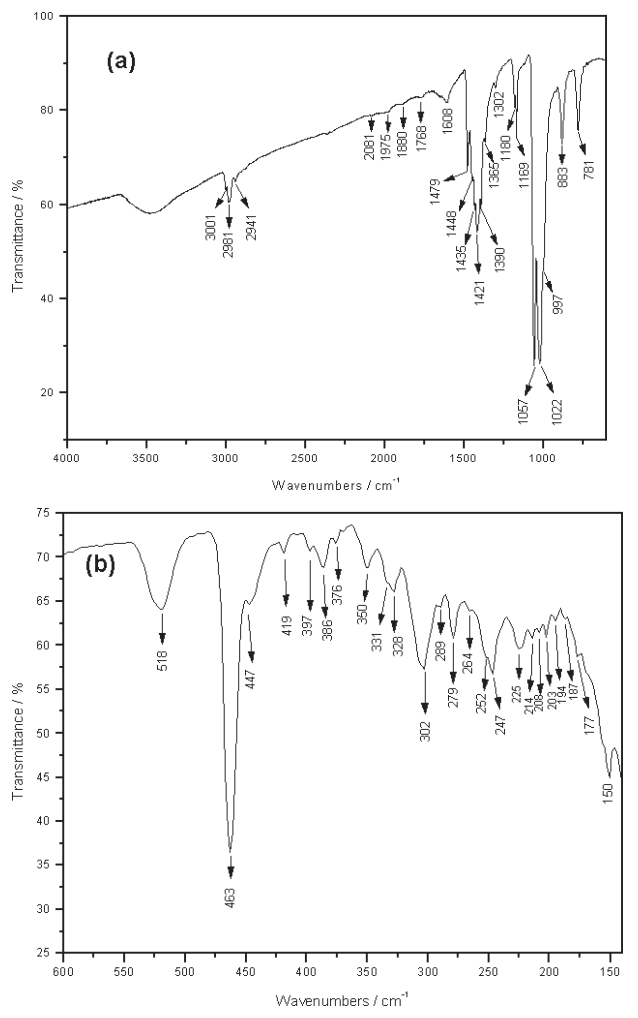

Figure 7. Infrared vibrational spectrum of the metal complex salt $\left[\mathrm{NEt}_{4}\right]\left[\mathrm{Bi}(\mathrm{dmit})_{2}\right]$ : (a) $4000-600$ and (b) $600-150 \mathrm{~cm}^{-1}$.
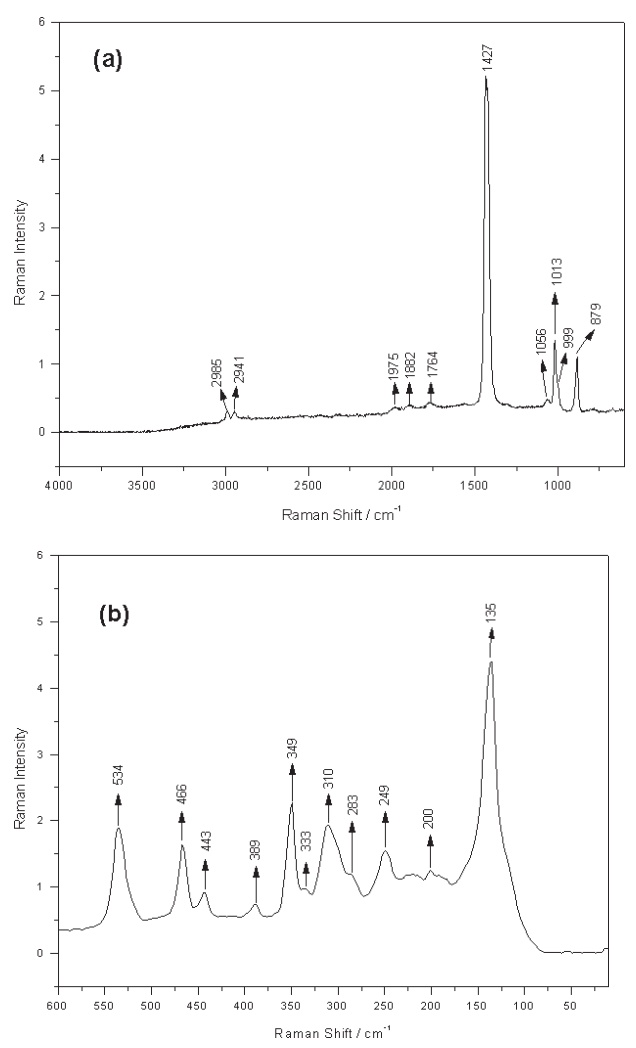

Figure 8. Vibrational Raman spectrum of the metal complex salt $\left[\mathrm{NEt}_{4}\right]\left[\mathrm{Bi}(\mathrm{dmit})_{2}\right]$ : (a) $4000-600$ and (b) $600-10 \mathrm{~cm}^{-1}$. 
infrared spectrum a band was observed, while the Raman band in this region was found at $283 \mathrm{~cm}^{-1}$ with a low intensity. In the region between 260 and $240 \mathrm{~cm}^{-1}$, two bands at 252 and $247 \mathrm{~cm}^{-1}$ were observed in the infrared, while in the Raman spectrum just one band was observed at $249 \mathrm{~cm}^{-1}$. Between 230 and $180 \mathrm{~cm}^{-1}$, several low intensity bands were observed in the infrared and Raman. At $134 \mathrm{~cm}^{-1}$ in the Raman spectrum, a single intense band was observed, assigned as the five-members-ring deformation formed by the metal coordination to the thiolate sulfur. This band has been found to have a linear dependency with the mass of the M-S bond along the bis(dmit) complex of zinc, antimony and bismuth.

The region from 2100 to $1700 \mathrm{~cm}^{-1}$ was investigated for overtones and combination bands. The bands at 2081 and $1880 \mathrm{~cm}^{-1}$, might be interpreted as combination of the

Table 6. Comparison between the observed and calculated wavenumbers $\left(\mathrm{cm}^{-1}\right)$ of vibrational spectra of $\left[\mathrm{NEt}{ }_{4}\right]\left[\mathrm{Bi}(\mathrm{dmit})_{2}\right]$

\begin{tabular}{|c|c|c|c|c|c|c|c|c|c|c|}
\hline \multicolumn{3}{|c|}{ RHF } & \multicolumn{2}{|c|}{ DFT } & \multicolumn{2}{|c|}{ MP2 } & \multirow[t]{2}{*}{ Symm. } & \multicolumn{2}{|c|}{ Exp. } & \multirow{2}{*}{$\begin{array}{l}\text { Mode } \\
\text { Assignment }\end{array}$} \\
\hline $\mathrm{cm}^{-1}$ & $\mathrm{I}_{\mathrm{IR}}$ & $\mathrm{I}_{\mathrm{RA}}$ & $\mathrm{cm}^{-1}$ & $\mathrm{I}_{\mathrm{IR}^{*}}$ & $\mathrm{~cm}^{-1}$ & $\mathrm{I}_{\mathrm{IR}}$ & & $\operatorname{IR}(s)$ & $\mathrm{R}(\mathrm{s})$ & \\
\hline 1770 & 43 & 17 & 1553 & 93 & 1506 & 103 & B & 1427 & 1427 & $v(\mathrm{C}=\mathrm{C})$ \\
\hline 1770 & 14 & 63 & 1553 & 25 & 1505 & 40 & A & & & $v(\mathrm{C}=\mathrm{C})$ \\
\hline 1089 & 374 & 0 & 1037 & 201 & 1051 & 295 & A & 1057 & 1056 & $v(\mathrm{C}=\mathrm{S})$ \\
\hline 1086 & 684 & 0 & 1035 & 641 & 1049 & 675 & B & 1020 & 1013 & $v(\mathrm{C}=\mathrm{S})$ \\
\hline 1059 & 1 & 3 & 934 & 4 & 950 & 5 & A & 997 & 999 & $v(\mathrm{Ce}-\mathrm{Sm})$ \\
\hline 1059 & 0 & 3 & 933 & 3 & 950 & 5 & B & & & $v(\mathrm{Ce}-\mathrm{Sm})$ \\
\hline 918 & 0 & 24 & 818 & 6 & 822 & 24 & A & & & $v(\mathrm{Ct}-\mathrm{Sa})$ \\
\hline 918 & 21 & 6 & 817 & 37 & 821 & 70 & $\mathrm{~B}$ & & & $v(\mathrm{Ct}-\mathrm{Sa})$ \\
\hline 904 & 30 & 39 & 809 & 29 & 816 & 3 & A & & 879 & $v(\mathrm{Ce}-\mathrm{Sm})+v(\mathrm{Ce}-\mathrm{Sa})$ \\
\hline 903 & 69 & 16 & 808 & 124 & 814 & 35 & $\mathrm{~B}$ & 883 & & $v(\mathrm{Ce}-\mathrm{Sm})+v(\mathrm{Ce}-\mathrm{Sa})$ \\
\hline 791 & 2 & 6 & 711 & 2 & 717 & 4 & A & & & $v(\mathrm{Ce}-\mathrm{Sm})+v(\mathrm{Ce}-\mathrm{Sa})+v(\mathrm{Ct}-\mathrm{Sa})$ \\
\hline 790 & 8 & 1 & 711 & 11 & 716 & 20 & $\mathrm{~B}$ & & & $v(\mathrm{Ce}-\mathrm{Sm})+v(\mathrm{Ce}-\mathrm{Sa})+v(\mathrm{Ct}-\mathrm{Sa})$ \\
\hline 652 & 0 & 1 & 540 & 0 & 528 & 0 & A & & & $\tau(\mathrm{SC}=\mathrm{CS})$ \\
\hline 650 & 0 & 1 & 539 & 0 & 526 & 0 & $\mathrm{~B}$ & & & $\tau(\mathrm{SC}=\mathrm{CS})$ \\
\hline 528 & 11 & 23 & 483 & 10 & 477 & 30 & A & 534 & 534 & $v(\mathrm{C}=\mathrm{S})+v(\mathrm{Ct}-\mathrm{S})$ \\
\hline 528 & 20 & 5 & 482 & 34 & 476 & 64 & $\mathrm{~B}$ & 518 & & $v(\mathrm{C}=\mathrm{S})+v(\mathrm{Ct}-\mathrm{S})$ \\
\hline 485 & 22 & 10 & 445 & 9 & 443 & 6 & $\mathrm{~A}$ & & & $\sigma(\mathrm{SCtS})+v(\mathrm{Ce}-\mathrm{Sm})+v(\mathrm{Ce}-\mathrm{Sa})$ \\
\hline 484 & 59 & 4 & 445 & 27 & 441 & 54 & $\mathrm{~B}$ & 463 & 466 & $\sigma(\mathrm{SCtS})+v(\mathrm{Ce}-\mathrm{Sm})+v(\mathrm{Ce}-\mathrm{Sa})$ \\
\hline 510 & 1 & 5 & 444 & 0 & 444 & 13 & A & 447 & 443 & $\omega(\mathrm{SCtS})$ \\
\hline 510 & 0 & 0 & 443 & 13 & 444 & 2 & $\mathrm{~B}$ & & & $\omega(\mathrm{SCtS})$ \\
\hline 415 & 1 & 8 & 377 & 1 & 382 & 2 & A & 386 & 389 & $\sigma(\mathrm{CCSm})+\rho(\mathrm{SCtS})$ \\
\hline 414 & 2 & 5 & 376 & 3 & 382 & 4 & $\mathrm{~B}$ & & & $\sigma(\mathrm{CCSm})+\rho(\mathrm{SCtS})$ \\
\hline 371 & 2 & 8 & 332 & 0 & 337 & 11 & $\mathrm{~B}$ & 350 & 349 & $\sigma(\mathrm{SmCeSa})+\sigma(\mathrm{SC}=\mathrm{S})+v(\mathrm{Bi}-\mathrm{S})$ \\
\hline 367 & 8 & 2 & 333 & 4 & 344 & 14 & A & & & $\sigma(\mathrm{SmCeSa})+\sigma(\mathrm{SC}=\mathrm{S})+v(\mathrm{Bi}-\mathrm{S})$ \\
\hline 358 & 0 & 17 & 329 & 0 & 330 & 0 & A & 331 & 333 & $\sigma(\mathrm{CeSaCt})+\sigma(\mathrm{CtSaCe})+v(\mathrm{Bi}-\mathrm{S})$ \\
\hline 354 & 1 & 11 & 322 & 2 & 329 & 0 & $\mathrm{~B}$ & 328 & & $\sigma(\mathrm{CeSaCt})+\sigma(\mathrm{CtSaCe})+v(\mathrm{Bi}-\mathrm{S})$ \\
\hline 324 & 12 & 35 & 293 & 6 & 298 & 4 & A & & 310 & $v(\mathrm{Bi}-\mathrm{S})+\chi(\mathrm{SC}=\mathrm{CS})+\sigma(\mathrm{SC}=\mathrm{S})$ \\
\hline 320 & 46 & 2 & 282 & 103 & 287 & 108 & $\mathrm{~B}$ & 302 & & $v(\mathrm{Bi}-\mathrm{S})+\chi(\mathrm{SC}=\mathrm{CS})+\sigma(\mathrm{SC}=\mathrm{S})$ \\
\hline 300 & 65 & 11 & 270 & 40 & 264 & 5 & $\mathrm{~B}$ & 279 & 283 & $\chi(\mathrm{SC}=\mathrm{CS})+\nu(\mathrm{Bi}-\mathrm{S})$ \\
\hline 304 & 4 & 17 & 270 & 0 & 262 & 0 & A & & & $\chi(\mathrm{SC}=\mathrm{CS})+\nu(\mathrm{Bi}-\mathrm{S})$ \\
\hline 256 & 0 & 27 & 232 & 0 & 240 & 0 & A & & & $v(\mathrm{Bi}-\mathrm{S})+\sigma(\mathrm{SC}=\mathrm{S})$ \\
\hline 243 & 93 & 1 & 229 & 40 & 234 & 75 & $\mathrm{~B}$ & 247 & 249 & $v(\mathrm{Bi}-\mathrm{S})+\sigma(\mathrm{SC}=\mathrm{S})$ \\
\hline 152 & 3 & 1 & 134 & 16 & 143 & 3 & B & & & $\sigma(\mathrm{SBiS})$ \\
\hline 148 & 9 & 4 & 133 & 3 & 139 & 12 & A & & 135 & $\sigma(\mathrm{SBiS})+\sigma(\mathrm{SC}=\mathrm{S})$ \\
\hline 138 & 96 & 6 & 133 & 50 & 133 & 52 & B & & & $\sigma(\mathrm{SBiS})+\tau(\mathrm{SmCeSa})$ \\
\hline 142 & 6 & 12 & 119 & 2 & 126 & 2 & A & & & $\sigma(\mathrm{SBiS})+\sigma(\mathrm{SC}=\mathrm{S})$ \\
\hline 122 & 0 & 8 & 111 & 0 & 109 & 0 & A & & & $\sigma(\mathrm{SBiS})+\tau(\mathrm{SmCeSa})$ \\
\hline 128 & 2 & 0 & 110 & 0 & 108 & 0 & $\mathrm{~B}$ & & & $\tau(\mathrm{SBiS})+\tau(\mathrm{SmCeSa})$ \\
\hline 108 & 5 & 15 & 93 & 3 & 95 & 4 & A & & & $\begin{array}{l}\omega(\mathrm{SBiS})+\tau(\mathrm{SmCeSa})+\chi(\mathrm{SC}=\mathrm{CS}) \\
+\tau(\mathrm{SC}=\mathrm{S})\end{array}$ \\
\hline 95 & 5 & 3 & 90 & 3 & 86 & 3 & $\mathrm{~B}$ & & & $\omega(\mathrm{SBiS})+\tau(\mathrm{SC}=\mathrm{S})$ \\
\hline 71 & 0 & 3 & 59 & 0 & 59 & 0 & A & & & $\omega(\mathrm{SBiS})+\chi \mathrm{c}(\mathrm{SC}=\mathrm{CS})+\tau(\mathrm{SC}=\mathrm{S})$ \\
\hline 53 & 1 & 2 & 44 & 0 & 45 & 0 & $\mathrm{~B}$ & & & $\chi(\mathrm{SmCCSa})+\sigma(\mathrm{SBiS})+\tau(\mathrm{SC}=\mathrm{S})$ \\
\hline 47 & 0 & 8 & 37 & 0 & 43 & 0 & A & & & $\chi(\mathrm{SmCeSa})+\sigma(\mathrm{SBiS})$ \\
\hline 25 & 0 & 3 & 24 & 0 & 23 & 0 & $\mathrm{~B}$ & & & $\sigma(\mathrm{SBiS})+\chi(\mathrm{SmCeSaCt})$ \\
\hline 10 & 0 & 12 & 11 & 0 & 10 & 0 & A & & & $\sigma(\mathrm{SBiS})+\chi(\mathrm{SmCCSa})$ \\
\hline
\end{tabular}

a Calculated infrared intensities $\left(\mathrm{I}_{\mathrm{IR}^{*}}\right)$ are in $\mathrm{KMmol}^{-1}$. Raman scattering activities $\left(\mathrm{I}_{\mathrm{RA}}\right)$ are in $\AA^{4} \mathrm{AMU} \mathrm{U}^{-1}$. ${ }^{\mathrm{b}} \mathrm{Ce}=$ carbon ethylenic, $\mathrm{Ct}=$ carbon of thione, $\mathrm{Sm}=$ linked sulfur to the metal, $\mathrm{Sa}=$ sulfur of the ring. 
1057, $1022 \mathrm{~cm}^{-1}$ and 1421, $463 \mathrm{~cm}^{-1}$ bands. On the other hand, the bands at 1975 and 1764 have been assigned as overtones of the 997 and $883 \mathrm{~cm}^{-1}$ fundamental bands.

\section{$\left.[\text { Bi(dmit })_{2}\right]^{-1}$ frequency calculations}

From the optimized geometries a hessian matrix calculation and frequency determination of all vibrational modes of $\left[\mathrm{Bi}(\mathrm{dmit})_{2}\right]^{-1}$ was carried out. All frequencies showed real modes. The frequencies and the corresponding intensities are shown in Table 6. As observed previously, only minor differences between the various basis sets/metal ECPs were detected. The results followed trends similar to the ones previously discussed in the zinc and antimony cases.

\section{Conclusions}

This work reports a combined theoretical-experimental investigation of the infrared and Raman vibrational spectra of three metal complexes with the 1,3-dithiole-2-thione4,5-dithiolate (dmit) ligand, namely, $\left[\mathrm{NEt}_{4}\right]_{2}\left[\mathrm{Zn}(\mathrm{dmit})_{2}\right]$, $\left[\mathrm{NEt}_{4}\right]\left[\mathrm{Sb}\left(\mathrm{dmit}_{2}\right]\right.$ and $\left[\mathrm{NEt}_{4}\right]\left[\mathrm{Bi}(\mathrm{dmit})_{2}\right]$. The IR and Raman spectra of all complexes have been recorded, and assigned, with an extensive set of $a b$ initio calculations carried out for validation and cross-checking.

Calculations carried out with several basis set and ECP potentials generated very similar results among them, as well as to the X-ray diffraction experimental results. Actually only minor differences were pointed in the text. The authors, however, claim this should not be considered a general conclusion for other metals and complexes. The metal-ligand character of dmit-complexes might be an important part of this observed behaviour. For other metal complexes and metal clusters molecular systems an additional study must be carried out. Within this possibility we still expect that the ECP and basis set choice should have an important role in the quality of the results. Major differences have been observed however with the use of different methodologies. RHF showed the worst results while DFT and MP2 calculations presented equivalent quality.

Starting from the observation of the spectra in solution of the $\left[\mathrm{NEt}_{4}\right]_{2}\left[\mathrm{Zn}(\mathrm{dmit})_{2}\right], \mathrm{C}=\mathrm{S}$ symmetrical and asymmetrical stretching modes were defined more clearly than in the solid state, becoming easily distinguishable and coherent with the present theoretical observations in 1059 and $1039 \mathrm{~cm}^{-1}$.

Most of the spectral data exhibit a spectrum composed of isolated fundamental bands for the systems without a strong M-S inter-molecular interaction. Within this pattern very few overtones, combinations bands and crystalline lattice vibrations have been observed in the spectra of the dmit-metal complexes. For the zinc complex, independently of the cation size, a similar spectrum was observed. On the other hand, for the dmit compounds where strong M-S inter-molecular interactions are present, significant deviations are observed, depending on the cation size and crystalline environment. The most clarifying example was found for the tetraethylammonium bismuth dmit complex for which a large difference among the BiSCC dihedral angle (20/25 degrees) was found between calculated and experimental results. Similarly significant overtones, combinations bands and crystalline effects appear in the spectrum. Although present on bismuth, for the antimony complex, whose is the same but with weaker M-S inter-molecular interactions, the spectra showed a simple fundamental behaviour.

\section{Acknowledgments}

Four authors (GBF, NMC, JLW and EH) acknowledge CNPq for financial support, and thank Dr. Nelson Morgon, from Universidade Estadual de Campinas, for submitting the MP2 jobs to Free-BSD Linux cluster, and Dr. Claudio Alberto Téllez Soto (UFF), for helpful discussions. The Pontifícia Universidade Católica do Rio de Janeiro is particularly acknowledged for the use of the Raman Nicolet FT-950 spectrophotometer.

\section{Electronic Supplementary Information}

Theoretical and vibrational analysis of tetraethylammonium bromide are available as a PDF file at http:// jbcs.sbq.org.br

\section{References}

1. Robertson, N.; Cronin, L.; Coord. Chem. Rev. 2002, 227, 93.

2. Pullen, A.E.; Olk, R.M.; Coord. Chem. Rev. 1999, 188, 211.

3. Cassoux, P.; Coord. Chem. Rev. 1999, 185, 213.

4. Brossard, L., Ribault, M., Bousseau, M., Valade, L., Cassoux, P.; C. R. Sci. (Paris) A Serie II 1986, 302, 205.

5. Akutagawa, T.; Nakamura, T.; Coord. Chem. Rev. 2000, 198, 297; Xue, G.; Yu, W. T.; Fang, Q.; Acta Cryst. 2003, 59C, m27; Cronin, L.; Clark, S. J.; Parsons, S.; Nakamura, T.; Robertson, N.; J. Chem. Soc. Dalton Trans. 2001, 1347.

6. Comerlato, N. M.; Harrison, W. T. A.; Howie, R. A.; Low, J. N.; Silvino, A. C.; Wardell, J. L.; Wardell, S. M. S V.; Acta Cryst. 2002, 58C, m105

7. Harrison, W. T. A.; Howie, R. A.; Wardell, J. L.; Wardell S. M. S. V.; Comerlato, N. M.; Costa, L. A. S.; Silvino, A. C.; de Oliveira, A. I.; Silva, R. M.; Polyhedron 2000, 19, 821. 
8. Chohan, Z. H.; Howie, R. A.; Wardell, J. L.; Wilkens, R., Doidge-Harrison, S. M. S. V.; Polyhedron 1997, 16, 2689.

9. Wang, H.; Zhu, D.; Zhu, N.; Fu, N.; Acta Phys. Sin. 1986, 35, 378.

10. Aupers, J. H.; Chohan, Z. H.; Comerlato, N. M.; Howie, R. A.; Silvino, A. C.; Wardell, J. L.; Wardell, S. M. S. V.; Polyhedron 2002, 21, 2107.

11. Marton, D.; Ganis, P.; Marton, D.; Spencer, G.M.; Wardell J.L.; Wardell, S.M.S.V.; Inorg. Chim. Acta 2000, 308, 139.

12. Doidge-Harrison, S. M. S. V.; Irvine, J. T. S.; Spencer, G. M.; Wardell, J. L.; Ganis, P.; Valle, G.; Tagliavini, G.; Inorg. Chem. 1995, 34, 4581.

13. Sheng, T.; Wu, X.; Lin, P.; Zhang, W.; Wang, Q.; Chen, L.; Polyhedron 1999, 18, 1049.

14. Comerlato, N. M.; Harrison, W. T. A.; Howie, R. A.; Silvino, A. C.; Wardell, J. L.; Wardell, S. M. S. V.; Inorg. Chem. Commun. 2000, 3, 572.

15. Comerlato, N. M.; Costa, L. A. S.; Howie, R. A.; Pereira, R. P.; Rocco, A. M.; Silvino, A. C.; Wardell, J. L.; Wardell, S. M. S. V.; Polyhedron 2001, 20, 415.

16. Matsuda, F.; Tamura, H.; Matsubayashi, G.; Inorg. Chim. Acta 1999, 295, 239.

17. Siimann, O.; Fresco, J.; Inorg. Chem. 1971, 10, 297.

18. Schläpfer, C. W.; Nakamoto, K.; Inorg. Chem. 1975, 14, 1338.

19. Barreto, W. J.; Santos, P. S.; J. Coord. Chem. 1993, 30, 337.

20. Aragoni, M. C.; Arca, M.; Demartin, F.; Devillanova, F. A.; Garau, A.; Isaia, F.; Lelj, F.; Lippolis, V.; Verani, G.; J. Am. Chem. Soc. 1999, 121, 7098.

21. Ramakumar, R.; Tanaka, Y.; Yamaji, K.; Phys. Rev. B 1997, 52,795 .

22. Ramakumar, R.; Yamaji, K.; Synth. Met. 2001, 120, 769.

23. Pokhodnya, K. I.; Faulmann, C.; Malfant, I.; Andreu-Solano, R.; Cassoux, P.; Mlayah, A.; Smirnov, D.; Leotin, J.; Synth. Met. 1999, 103, 2016.

24. Dyer, C. D., Kilburn, J. D.; Maddams, W. F.; Walker, P. A.; Spectrochim. Acta 1991, 47A, 1225.

25. Schmidt, M. W.; Baldridge, K. K.; Boatz, J. A.; Elbert, S. T.; Gordon, M. S.; Jensen, J. H.; Koseki, S.; Matsunaga, N.; Nguyen, K. A.; Su, S. J.; Windus, T. L.; Gamess Version R5; Iowa State University, 2001.

26. Frisch, M. J.; Trucks, G. W.; Schlegel, H. B.; Scuseria, G. E.; Robb, M. A.; Cheeseman, J. R.; Zakrzewski, V. G.; Montgomery, J. A.; Stratmann, R. E.; Burant, J. C.; Dapprich,
S.; Millam, J. M.; Daniels, A. D.; Kudin, K. N.; Strain, M. C.; Farkas, O.; Tomasi, J.; Barone, V.; Cossi, M.; Cammi, R.; Mennucci, B.; Pomelli, C.; Adamo, C.; Clifford, S.; Ochterski, J.; Petersson, G. A.; Ayala, P. Y.; Cui, Q.; Morokuma, K.; Malick, D. K.; Rabuck, A. D.; Raghavachari, K.; Foresman, J. B.; Cioslowski, J.; Ortiz, J. V.; Baboul, A. G.; Stefanov, B. B.; Liu, G.; Liashenko, A.; Piskorz, P.; Komaromi, I.; Gomperts, R.; Martin, R. L.; Fox, D. J.; Keith, T.; Al-Laham, M. A.; Peng, C. Y.; Nanayakkara, A.; Gonzalez, C.; Challacombe, M.; Gill, P. M. W.; Johnson, B.; Chen, W.; Wong, M. W.; Andres, J. L.; Gonzalez, C.; Head-Gordon, M.; Replogle, E. S.; Pople, J. A.; Gaussian 98, Revision A.7; Gaussian, Inc.: Pittsburgh PA, 1998.

27. Stevens, W. J.; Krauss, M.; Basch, H.; Jasien, P. G.; Can. J. Chem. 1992, 70, 612.

28. Dolg, M.; Stoll, H.; Preuss, H.; Pitzer, R. M.; J. Phys. Chem. 1993, 97, 5852.

29. Noordik, J. H.; Schaftenaar, G.; J. Comput.-Aided Mol. Design 2000, 14, 123.

30. Flükiger, P.; Lüthi, H. P.; Portmann, S.; Weber, J.; MOLEKEL 4.3, Swiss Center for Scientific Computing, Manno (Switzerland), 2000.

31. Hooper, M. A.; James, D.W.; Austr. J. Chem. 1971, 24, 1345.

32. Cassoux, P.; Pokhodnya, K. I.; Faulmann, C.; Malfant, I.; Andreu-Solano, R.; Mlayah, A.; Smirnov, D.; Leotin, J.; Synth. Met. 1999, 103, 2016.

33. Radom, L.; Scott, A. P.; J. Phys. Chem. 1996, 100, 16502.

34. Hollauer, E., Ramos; J. C. S.; Quim. Nova 1999, 22, 684; Carauta, A. N. M.; Souza, V.; Hollauer, E.; Soto, C. A. T.; Spectrochim. Acta A 2004, 60, 41; Soto, C. A. T; Hollauer, E.; Felcman, J.; Lopes, D. C. N.; Cattapan, R.; Spectrochim. Acta A 2002, 58, 1853; Soto, C. A. T; Hollauer, E.; Pais da Silva, M. I.; Mondragón, M. A.; Haiduc, I.; Curtui, M.; Spectrochim. Acta A 2001, 57, 1149; Soto, C. A. T; de la Riva, S.; Hollauer, E.; Haiduc, I.; Silvestru, C. S.; Spectrosc. Lett. 1998, 31, 1469.

35. Ratajczak, H.; Baran, J.; Sledz, M.; Drozd, M.; Pietraszko, A.; Haznar, A.; J. Mol. Struct. 2000, 526, 361.

36. Zeegers-Huyskens, T.; Bator, G.; Vib. Spectrosc. 1996, 13, 41.

37. Beer, W. H. J., Heyns, A. M.; Spectrochim. Acta 1981, 37A, 1099.

Received: August 25, 2003 Published on the web: November 18, 2004 


\title{
Vibrational Spectra of Bis(dmit) Complexes of Main Group Metals: IR, Raman and $A b$ Initio Calculations
}

\author{
Glaucio B. Ferreira ${ }^{a}$, Nadia M. Comerlato ${ }^{a}$, James L. Wardell ${ }^{a}$ and Eduardo Hollauer $^{*, b}$ \\ ${ }^{a}$ Instituto de Química, Universidade Federal do Rio de Janeiro, CP 68563, 21945-970 Rio de Janeiro - RJ, Brazil \\ ${ }^{b}$ Instituto de Química, Universidade Federal Fluminense, Outeiro de São João Batista s/n, Centro, 24210-130 \\ Niterói - RJ, Brazil
}

\section{Results}

\section{Tetraethylammonium bromide $\mathrm{NEt}_{4} \mathrm{Br}$}

The infrared and Raman spectra of $\mathrm{NEt}_{4} \mathrm{Br}$ were obtained and a complete assignment of all the vibrations associated with the cation was made, aided by ab initio calculations.

\section{$\left[\mathrm{NEt}_{4}\right]^{+}$geometry optimization}

Several symmetries have been found for the $\left[\mathrm{NEt}_{4}\right]^{+}$ cation $^{35-37}$ in its various salts: the one found by X-ray crystallography for the salts studied here is $\mathrm{D}_{2 \mathrm{~d}}{ }^{7,12,15}$ Figure 1. As no metal atom is present, all atoms in the calculations were represented by a single basis set. Table 1 lists the main geometrical parameters calculated by the different $a b$ initio methods for the $\left[\mathrm{NEt}_{4}\right]^{+}$cation. It is clear that the calculated main geometric parameters are insensitive to the method used, all indeed giving geometric parameters close to those found in the the X-ray diffraction study.

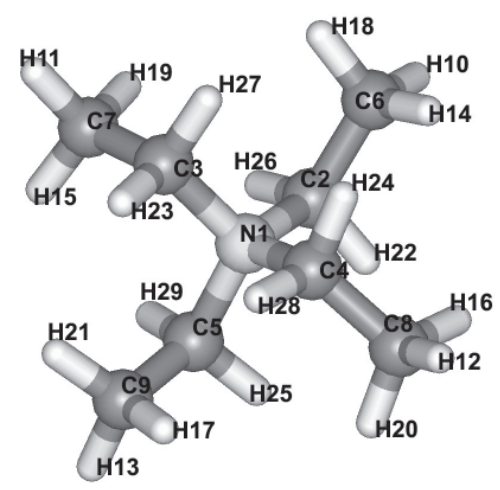

Figure 1. Three-dimensional representation of tetraethylammonium calculated with $a b$ initio method.

* e-mail: edu@kabir.gqt.uff.br
Table 1. Main geometrical parameters for the tetraethylammonium cation calculated with $a b$ initio methods and 6-31G basis set

\begin{tabular}{lrrrr}
\hline & RHF & DFT & MP2 & Exp. \\
\hline Bond $(\AA)$ & & & & \\
$\mathrm{N}^{1}-\mathrm{C}^{2}$ & 1.5287 & 1.5469 & 1.5518 & 1.5176 \\
$\mathrm{C}^{2}-\mathrm{C}^{6}$ & 1.5223 & 1.5255 & 1.5345 & 1.5031 \\
$\mathrm{C}^{2}-\mathrm{H}^{26}$ & 1.0780 & 1.0916 & 1.0956 & 0.9699 \\
$\mathrm{C}^{6}-\mathrm{H}^{10}$ & 1.0830 & 1.0934 & 1.0986 & 0.9601 \\
Bend $\left(^{o}\right)$ & & & & \\
$\mathrm{C}^{5} \mathrm{NC}^{2}$ & 106.2 & 106.5 & 106.4 & 106.9 \\
$\mathrm{C}^{6} \mathrm{C}^{2} \mathrm{~N}$ & 116.0 & 115.8 & 115.5 & 115.6 \\
$\mathrm{C}^{2} \mathrm{C}^{6} \mathrm{H}^{14}$ & 113.1 & 113.1 & 112.7 & 109.5 \\
$\mathrm{C}^{2} \mathrm{C}^{6} \mathrm{H}^{10}$ & 107.5 & 107.6 & 107.4 & 109.5 \\
$\mathrm{C}^{2} \mathrm{C}^{6} \mathrm{H}^{18}$ & 113.1 & 113.1 & 112.7 & 109.5 \\
$\mathrm{NC}^{2} \mathrm{H}^{26}$ & 106.1 & 105.7 & 105.6 & 108.4 \\
$\mathrm{NC}^{2} \mathrm{H}^{22}$ & 106.1 & 105.7 & 105.6 & 108.3 \\
Dihedral $\left({ }^{o}\right)$ & & & & \\
$\mathrm{NC}^{2} \mathrm{C}^{6} \mathrm{H}^{10}$ & 180.0 & 180.0 & 180.0 & 176.4 \\
$\mathrm{NC}^{2} \mathrm{C}^{6} \mathrm{H}^{14}$ & 62.2 & 62.1 & 62.1 & 56.4 \\
$\mathrm{NC}^{2} \mathrm{C}^{6} \mathrm{H}^{18}$ & 62.2 & 62.2 & 62.1 & 63.6 \\
$\mathrm{H}^{10} \mathrm{C}^{6} \mathrm{C}^{2} \mathrm{H}^{22}$ & 59.7 & 59.7 & 59.9 & 65.1 \\
$\mathrm{H}^{10} \mathrm{C}^{6} \mathrm{C}^{2} \mathrm{H}^{26}$ & 59.3 & 59.7 & 59.9 & 58.6 \\
\hline
\end{tabular}

$\left[\mathrm{NEt}_{4}\right]^{+}$experimental frequencies

For the $\mathrm{D}_{2 \mathrm{~d}}$ point group, the molecular cartesian displacement representation and its irreducible composition lead to 81 vibration modes; $\Gamma_{\text {vibration }}=12 \mathrm{~A}_{1}+$ $8 \mathrm{~A}_{2}+9 \mathrm{~B}_{1}+12 \mathrm{~B}_{2}+20 \mathrm{E}$. From these, 52 are infrared active $\left(\mathrm{B}_{2}\right.$ and $\left.\mathrm{E}\right)$ and 73 are Raman active $\left(\mathrm{A}_{1}, \mathrm{~B}_{1}, \mathrm{~B}_{2}\right.$ and $\left.\mathrm{E}\right)$.

The infrared and Raman spectra of several tetraethylammonium salts have been reported. ${ }^{31,32}$ Figures 2 and 3 show the infrared and Raman spectra of tetraethylammonium bromide, respectively. According to Hooper and James, ${ }^{31}$ the modes at 2999 and $2983 \mathrm{~cm}^{-1}$ in the infrared spectrum are assigned as asymmetric stretches, within $\mathrm{CH}_{3}$ and $\mathrm{CH}_{2}$ respectively, while the bands at 2970 and $2944 \mathrm{~cm}^{-1}$ in the Raman spectrum are symmetrical $\mathrm{CH}_{3}$ and $\mathrm{CH}_{2}$ stretches, respectively. Bands between 2960 
and $1500 \mathrm{~cm}^{-1}$ are, most probably, overtone and combinations bands. The region between 1500 and 1100 $\mathrm{cm}^{-1}$ is characteristic of $\mathrm{HCH}$ bending modes, including scissoring, wagging, twisting and rocking modes. A set of bands between 1493 and $1440 \mathrm{~cm}^{-1}$ has been assigned as asymmetric and symmetric $\mathrm{CH}_{3}$ scissoring modes. The bands between 1415 and $1390 \mathrm{~cm}^{-1}$ and the band at 1378 $\mathrm{cm}^{-1}$ are assigned as $\mathrm{CH}_{2}$ scissoring modes. The Raman active band at $1304 \mathrm{~cm}^{-1}$ has been assigned as $\mathrm{CH}_{2}$ twisting mode. Two very intense bands at 1183 and $1175 \mathrm{~cm}^{-1}$ in the infrared spectrum have been assigned to $\mathrm{CH}_{3}$ asymmetrical rocking modes and that at $1116 \mathrm{~cm}^{-1}$ to a symmetrical rocking mode in the Raman spectrum.

In the region below $1100 \mathrm{~cm}^{-1}$, many $\mathrm{C}-\mathrm{N}$ and $\mathrm{C}-\mathrm{C}$ stretching modes are present. Low intensity bands at 1071 and $1050 \mathrm{~cm}^{-1}$ have been assigned as C-C asymmetrical stretching. A shoulder at $1030 \mathrm{~cm}^{-1}$ has been assigned as an asymmetric $\mathrm{C}-\mathrm{N}$ stretch, while the intense band present at $1009 \mathrm{~cm}^{-1}$ in the infrared spectrum is assigned as a $\mathrm{CH}_{3}$ rocking mode. Two low intensity bands at 910 and 898 $\mathrm{cm}^{-1}$ have been considered C-C symmetric stretching, while the bands at 802 and $789 \mathrm{~cm}^{-1}$ have been assigned as rocking of the $\mathrm{CH}_{2}$ group. The Raman active band at 679 $\mathrm{cm}^{-1}$ was considered by Hooper and James as the C-N
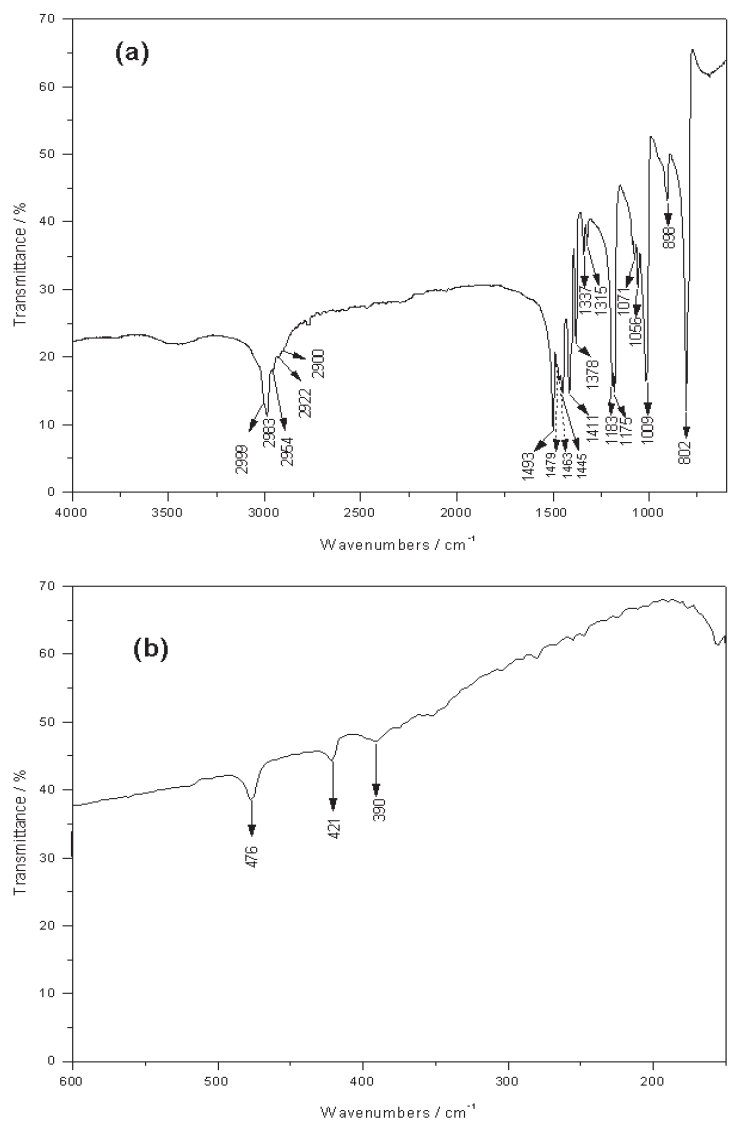

Figure 2. Infrared vibrational spectrum of the tetraethylammonium bromide: (a) 4000-600 and (b) $600-100 \mathrm{~cm}^{-1}$. characteristic symmetric stretching mode.

In the low wavenumber region of the spectra, the few low intensity bands have been assigned to the deformation of the CCN frame. Only in the Raman spectrum was observed an intense mode at $422 \mathrm{~cm}^{-1}$ The 476, 421 and $390 \mathrm{~cm}^{-1}$ bands in the infrared spectrum have been assigned to the asymmetric $\mathrm{CNC}, \mathrm{CCN}$ and symmetric CNC vibrational modes. Hooper and James no inform about the presence of bands below $390 \mathrm{~cm}^{-1}$.

\section{$\left[\mathrm{NEt}_{4}\right]^{+}$frequency calculations}

Frequencies and intensities were calculated for the infrared and Raman spectra. All frequencies showed real modes, as expected for an equilibrium geometry. The proposed assignments, based on ab initio calculations for all 81 vibrational modes present in $\mathrm{NEt}_{4} \mathrm{Br}$, is found on Table 2, with the previous conventions adopted.

For this molecule we employed RHF, DFT and MP2 methods with a single basis set to check the identification of the IR/Raman cationic bands in the spectra of the complex salts..$^{33,34}$ The most significant bands of $\left[\mathrm{NEt}_{4}\right]^{+}$ were observed from 3000 to $2900 \mathrm{~cm}^{-1}$, from 1500 to 1100 $\mathrm{cm}^{-1}$, at $785 \mathrm{~cm}^{-1}$ and at $419 \mathrm{~cm}^{-1}$.
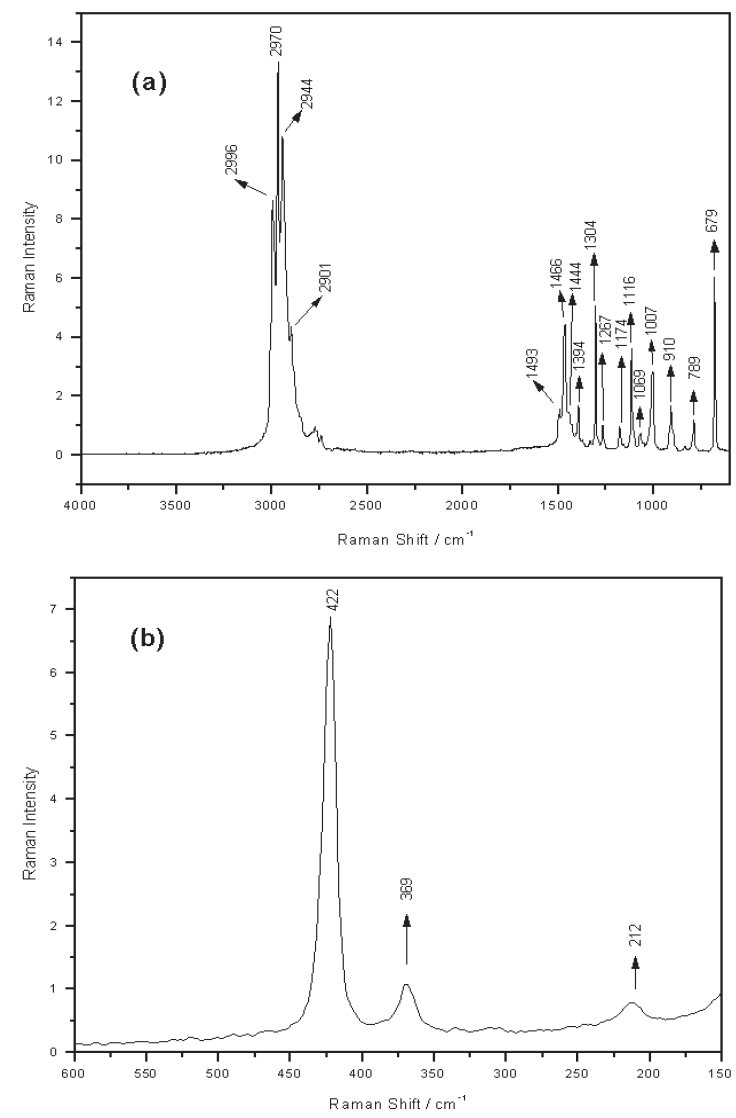

Figure 3. Vibrational Raman spectrum of the tetraethylammonium bromide: (a) 4000-600 and (b) $600-150 \mathrm{~cm}^{-1}$. 
Table 2. Comparison between the observed and calculated wavenumbers $\left(\mathrm{cm}^{-1}\right)$ of vibrational spectra of $\mathrm{NEt}_{4} \mathrm{Br}$

\begin{tabular}{|c|c|c|c|c|c|c|c|c|c|c|}
\hline \multicolumn{3}{|c|}{ RHF } & \multicolumn{2}{|c|}{ DFT } & \multicolumn{2}{|c|}{ MP2 } & \multirow[t]{2}{*}{ Symm. } & \multicolumn{2}{|c|}{ Exp. } & \multirow{2}{*}{$\begin{array}{l}\text { Mode } \\
\text { Assignment }\end{array}$} \\
\hline $\mathrm{cm}^{-1}$ & $\mathrm{I}_{\mathrm{IR}}$ & $\mathrm{I}_{\mathrm{RA}}$ & $\mathrm{cm}^{-1}$ & $\mathrm{I}_{\mathrm{IR}^{*}}$ & $\mathrm{~cm}^{-1}$ & $\mathrm{I}_{\mathrm{IR}}$ & & $\operatorname{IR}(\mathrm{s})$ & $\mathrm{R}(\mathrm{s})$ & \\
\hline 3346 & 0.50 & 42.2 & 3180 & 26 & 3193 & 0.65 & $\mathrm{E}$ & & & $v(\mathrm{C}-\mathrm{H}) /\left(\mathrm{CH}_{3}+\mathrm{CH}_{2}\right)$ \\
\hline 3346 & 0.50 & 42.2 & 3180 & 26 & 3193 & 0.65 & $\mathrm{E}$ & 2999 & 2996 & $v(\mathrm{C}-\mathrm{H}) /\left(\mathrm{CH}_{3}+\mathrm{CH}_{2}\right)$ \\
\hline 3342 & 0.00 & 3.0 & 3179 & 0 & 3195 & 0.00 & $\mathrm{~B}_{1}$ & & & $v(\mathrm{C}-\mathrm{H}) /\left(\mathrm{CH}_{3}+\mathrm{CH}_{2}\right)$ \\
\hline 3331 & 0.00 & 0.0 & 3169 & 0 & 3182 & 0.00 & $\mathrm{~A}_{2}$ & & & $v(\mathrm{C}-\mathrm{H}) /\left(\mathrm{CH}_{3}+\mathrm{CH}_{2}\right)$ \\
\hline 3307 & 0.38 & 120.3 & 3155 & 6 & 3175 & 0.06 & $\mathrm{E}$ & & & $v(\mathrm{C}-\mathrm{H}) /\left(\mathrm{CH}_{3}+\mathrm{CH}_{2}\right)$ \\
\hline 3307 & 0.38 & 120.3 & 3155 & 6 & 3175 & 0.06 & $\mathrm{E}$ & & & $v(\mathrm{C}-\mathrm{H}) /\left(\mathrm{CH}_{3}+\mathrm{CH}_{2}\right)$ \\
\hline 3306 & 0.00 & 0.0 & 3156 & 0 & 3174 & 0.00 & $\mathrm{~A}_{2}$ & & & $v(\mathrm{C}-\mathrm{H}) /\left(\mathrm{CH}_{3}+\mathrm{CH}_{2}\right)$ \\
\hline 3301 & 1.12 & 15.3 & 3149 & 28 & 3172 & 0.44 & $\mathrm{~B}_{2}^{2}$ & 2983 & & $v(\mathrm{C}-\mathrm{H}) /\left(\mathrm{CH}_{3}+\mathrm{CH}_{2}\right)$ \\
\hline 3298 & 0.00 & 33.0 & 3147 & 0 & 3170 & 0.00 & $\mathrm{~B}_{1}^{2}$ & & & $v(\mathrm{C}-\mathrm{H}) /\left(\mathrm{CH}_{3}+\mathrm{CH}_{2}\right)$ \\
\hline 3292 & 0.00 & 31.4 & 3145 & 0 & 3168 & 0.00 & $\mathrm{E}$ & & & $v(\mathrm{C}-\mathrm{H}) /\left(\mathrm{CH}_{2}\right)$ \\
\hline 3292 & 0.00 & 31.4 & 3145 & 0 & 3168 & 0.00 & $\mathrm{E}$ & & & $v(\mathrm{C}-\mathrm{H}) /\left(\mathrm{CH}_{2}\right)$ \\
\hline 3292 & 0.00 & 166.3 & 3146 & 0 & 3163 & 0.00 & $\mathrm{~A}_{1}$ & & 2970 & $v(\mathrm{C}-\mathrm{H}) /\left(\mathrm{CH}_{3}+\mathrm{CH}_{2}\right)$ \\
\hline 3279 & 0.00 & 160.3 & 3119 & 10 & 3123 & 0.36 & $\mathrm{~B}_{2}$ & 2954 & & $v(\mathrm{C}-\mathrm{H}) /\left(\mathrm{CH}_{2}\right)$ \\
\hline 3289 & 0.00 & 96.0 & 3121 & 0 & 3122 & 0.00 & $\mathrm{~A}_{1}^{2}$ & & 2944 & $v(\mathrm{C}-\mathrm{H}) /\left(\mathrm{CH}_{2}\right)$ \\
\hline 3275 & 0.11 & 24.4 & 3112 & 3 & 3115 & 0.05 & $\mathrm{E}$ & 2922 & & $v(\mathrm{C}-\mathrm{H}) /\left(\mathrm{CH}_{2}\right)$ \\
\hline 3275 & 0.11 & 24.4 & 3112 & 3 & 3115 & 0.05 & $\mathrm{E}$ & & & $v(\mathrm{C}-\mathrm{H}) /\left(\mathrm{CH}_{2}\right)$ \\
\hline 3221 & 0.12 & 2.7 & 3075 & 6 & 3087 & 0.10 & $\mathrm{~B}_{2}$ & & & $v(\mathrm{C}-\mathrm{H}) /\left(\mathrm{CH}_{3}\right)$ \\
\hline 3220 & 0.18 & 15.6 & 3075 & 3 & 3087 & 0.06 & $\mathrm{E}$ & 2900 & & $v(\mathrm{C}-\mathrm{H}) /\left(\mathrm{CH}_{3}\right)$ \\
\hline 3220 & 0.18 & 15.6 & 3075 & 3 & 3087 & 0.06 & $\mathrm{E}$ & & & $v(\mathrm{C}-\mathrm{H}) /\left(\mathrm{CH}_{3}\right)$ \\
\hline 3220 & 0.00 & 392.2 & 3074 & 0 & 3086 & 0.00 & $\mathrm{~A}_{1}$ & & & $v(\mathrm{C}-\mathrm{H}) /\left(\mathrm{CH}_{3}\right)$ \\
\hline 1693 & 1.49 & 0.2 & 1570 & 52 & 1590 & 1.23 & $\mathrm{~B}_{2}$ & 1493 & 1493 & $\sigma(\mathrm{HCH}) /\left(\mathrm{CH}_{2}\right)$ \\
\hline 1691 & 0.00 & 9.3 & 1571 & 0 & 1588 & 0.00 & $\mathrm{~A}_{1}$ & & & $\sigma(\mathrm{HCH}) /\left(\mathrm{CH}_{2}\right)$ \\
\hline 1679 & 0.19 & 1.0 & 1566 & 17 & 1585 & 0.36 & $\mathrm{E}$ & 1479 & & $\sigma(\mathrm{HCH}) /\left(\mathrm{CH}_{2}+\mathrm{CH}_{3}\right)$ \\
\hline 1679 & 0.19 & 1.0 & 1566 & 17 & 1585 & 0.36 & $\mathrm{E}$ & & & $\sigma(\mathrm{HCH}) /\left(\mathrm{CH}_{2}+\mathrm{CH}_{3}\right)$ \\
\hline 1663 & 0.00 & 59.4 & 1547 & 0 & 1574 & 0.00 & $\mathrm{~A}_{1}$ & & & $\sigma(\mathrm{HCH}) /\left(\mathrm{CH}_{3}^{2}\right)$ \\
\hline 1657 & 0.03 & 5.0 & 1546 & 4 & 1570 & 0.06 & $\mathrm{E}$ & & & $\sigma(\mathrm{HCH}) /\left(\mathrm{CH}_{3}+\mathrm{CH}_{2}\right)$ \\
\hline 1657 & 0.03 & 5.0 & 1546 & 3 & 1570 & 0.06 & $\mathrm{E}$ & & & $\sigma(\mathrm{HCH}) /\left(\mathrm{CH}_{3}+\mathrm{CH}_{2}\right)$ \\
\hline 1657 & 0.00 & 80.8 & 1549 & 0 & 1569 & 0.00 & $\mathrm{~B}_{1}$ & & 1466 & $\sigma(\mathrm{HCH}) /\left(\mathrm{CH}_{3}\right)$ \\
\hline 1656 & 0.00 & 0.0 & 1548 & 0 & 1568 & 0.00 & $\mathrm{~A}_{2}$ & & & $\sigma(\mathrm{HCH}) /\left(\mathrm{CH}_{3}\right)$ \\
\hline 1650 & 0.51 & 0.0 & 1537 & 33 & 1563 & 0.54 & $\mathrm{~B}_{2}$ & 1463 & & $\sigma(\mathrm{HCH}) /\left(\mathrm{CH}_{3}\right)$ \\
\hline 1642 & 0.77 & 0.3 & 1524 & 22 & 1547 & 0.48 & $\mathrm{E}^{2}$ & 1445 & 1444 & $\sigma(\mathrm{HCH}) /\left(\mathrm{CH}_{3}+\mathrm{CH}_{2}\right)$ \\
\hline 1642 & 0.77 & 0.3 & 1524 & 22 & 1547 & 0.48 & $\mathrm{E}$ & & & $\sigma(\mathrm{HCH}) /\left(\mathrm{CH}_{3}+\mathrm{CH}_{2}\right)$ \\
\hline 1601 & 0.00 & 13.9 & 1482 & 0 & 1500 & 0.00 & $\mathrm{~A}_{1}$ & & 1394 & $\omega(\mathrm{HCH}) /\left(\mathrm{CH}_{3}\right)$ \\
\hline 1604 & 0.04 & 2.6 & 1481 & 3 & 1500 & 0.07 & $\mathrm{~B}_{2}$ & & & $\omega(\mathrm{HCH}) /\left(\mathrm{CH}_{3}\right)$ \\
\hline 1600 & 0.81 & 1.2 & 1480 & 35 & 1500 & 0.78 & $\mathrm{E}$ & 1411 & & $\omega(\mathrm{HCH}) /\left(\mathrm{CH}_{3}\right)$ \\
\hline 1600 & 0.81 & 1.2 & 1480 & 35 & 1500 & 0.78 & $\mathrm{E}$ & & & $\omega(\mathrm{HCH}) /\left(\mathrm{CH}_{3}\right)$ \\
\hline 1587 & 0.00 & 5.6 & 1461 & 0 & 1474 & 0.03 & $\mathrm{~B}_{2}$ & 1378 & & $\omega(\mathrm{HCH}) /\left(\mathrm{CH}_{3}+\mathrm{CH}_{2}\right)$ \\
\hline 1582 & 0.00 & 4.3 & 1456 & 0 & 1469 & 0.00 & $\mathrm{~A}_{1}^{2}$ & & & $\omega(\mathrm{HCH}) /\left(\mathrm{CH}_{3}+\mathrm{CH}_{2}\right)$ \\
\hline 1533 & 0.61 & 0.8 & 1409 & 18 & 1421 & 0.32 & $\mathrm{E}$ & 1335 & & $\tau(\mathrm{HCH})+\omega(\mathrm{HCH}) /\left(\mathrm{CH}_{2}\right)$ \\
\hline 1533 & 0.61 & 0.8 & 1409 & 18 & 1421 & 0.32 & $\mathrm{E}$ & & & $\tau(\mathrm{HCH})+\omega(\mathrm{HCH}) /\left(\mathrm{CH}_{2}\right)$ \\
\hline 1506 & 0.02 & 0.7 & 1388 & 0 & 1396 & 0.04 & $\mathrm{E}$ & 1317 & & $\tau(\mathrm{HCH})+\omega(\mathrm{HCH}) /\left(\mathrm{CH}_{2}\right)$ \\
\hline 1506 & 0.02 & 0.7 & 1388 & 0 & 1396 & 0.04 & $\mathrm{E}$ & & & $\tau(\mathrm{HCH})+\omega(\mathrm{HCH}) /\left(\mathrm{CH}_{2}\right)$ \\
\hline 1455 & 0.00 & 36.0 & 1343 & 0 & 1351 & 0.00 & $\mathrm{~B}_{1}$ & & 1304 & $\omega(\mathrm{HCH}) /\left(\mathrm{CH}_{2}\right)$ \\
\hline 1433 & 0.00 & 0.0 & 1324 & 0 & 1337 & 0.00 & $\mathrm{~A}_{2}$ & & & $\omega(\mathrm{HCH}) /\left(\mathrm{CH}_{2}\right)$ \\
\hline 1352 & 0.11 & 0.1 & 1242 & 2 & 1266 & 0.04 & $\mathrm{E}^{2}$ & & & $\rho(\mathrm{HCH}) /\left(\mathrm{CH}_{2}\right)$ \\
\hline 1352 & 0.11 & 0.1 & 1242 & 2 & 1266 & 0.04 & $\mathrm{E}$ & & & $\rho(\mathrm{HCH}) /\left(\mathrm{CH}_{3}^{2}\right)$ \\
\hline 1306 & 0.00 & 0.0 & 1203 & 0 & 1222 & 0.00 & $\mathrm{~B}_{1}$ & & & $\rho(\mathrm{HCH}) /\left(\mathrm{CH}_{2}+\mathrm{CH}_{3}\right)$ \\
\hline 1306 & 1.31 & 4.1 & 1194 & 29 & 1212 & 0.66 & $\mathrm{~B}_{2}$ & $1185 / 75$ & 1174 & $\omega(\mathrm{HCH}) /\left(\mathrm{CH}_{3}\right)$ \\
\hline 1248 & 0.00 & 13.3 & 1157 & 0 & 1168 & 0.00 & $\mathrm{~A}_{1}^{2}$ & & 1116 & $\omega(\mathrm{HCH}) /\left(\mathrm{CH}_{3}\right)$ \\
\hline 1244 & 0.00 & 0.0 & 1140 & 0 & 1157 & 0.00 & $\mathrm{~A}_{2}$ & & & $\rho(\mathrm{HCH})+\sigma \mathrm{CCN}\left(\mathrm{CH}_{3}+\mathrm{CH}_{2}\right)$ \\
\hline 1200 & 0.19 & 2.5 & 1109 & 7 & 1116 & 0.13 & $\mathrm{E}$ & 1071 & 1069 & $\omega(\mathrm{HCH}) /\left(\mathrm{CH}_{3}\right)$ \\
\hline 1200 & 0.19 & 2.5 & 1109 & 7 & 1116 & 0.13 & $\mathrm{E}$ & & & $\omega(\mathrm{HCH}) /\left(\mathrm{CH}_{3}\right)$ \\
\hline 1141 & 0.50 & 1.5 & 1065 & 16 & 1082 & 0.33 & $\mathrm{~B}_{2}$ & 1056 & & $v(\mathrm{C}-\mathrm{C})+v(\mathrm{~N}-\mathrm{C})$ \\
\hline 1121 & 0.00 & 4.4 & 1052 & 0 & 1058 & 0.00 & $\mathrm{~A}_{1}^{2}$ & & & $v(\mathrm{C}-\mathrm{C})+v(\mathrm{~N}-\mathrm{C})$ \\
\hline 1094 & 0.64 & 9.8 & 1020 & 21 & 1030.6 & 0.42 & $\mathrm{E}$ & 1010 & 1007 & $v(\mathrm{C}-\mathrm{C})+v(\mathrm{~N}-\mathrm{C})$ \\
\hline 1094 & 0.64 & 9.8 & 1020 & 21 & 1031 & 0.42 & $\mathrm{E}$ & & & $v(\mathrm{C}-\mathrm{C})+v(\mathrm{~N}-\mathrm{C})$ \\
\hline 990 & 0.08 & 8.4 & 904 & 0 & 910 & 0.00 & $\mathrm{~B}_{2}$ & 898 & 910 & $\omega(\mathrm{CCH})+\sigma(\mathrm{CCN})$ \\
\hline 974 & 0.03 & 1.2 & 902 & 0 & 909 & 0.00 & $\mathrm{E}^{2}$ & & & $v(\mathrm{~N}-\mathrm{C})+\rho(\mathrm{CCH})$ \\
\hline 974 & 0.03 & 1.2 & 902 & 0 & 909 & 0.00 & $\mathrm{E}$ & & & $v(\mathrm{~N}-\mathrm{C})+\rho(\mathrm{CCH})$ \\
\hline 916 & 0.00 & 0.7 & 850 & 0 & 852 & 0.00 & $\mathrm{~B}_{1}$ & & & $\rho(\mathrm{HCH}) /\left(\mathrm{CH}_{2}+\mathrm{CH}_{3}\right)$ \\
\hline 862 & 0.00 & 0.0 & 801 & 0 & 796 & 0.00 & $\mathrm{~A}_{2}$ & & & $\rho(\mathrm{HCH}) /\left(\mathrm{CH}_{2}+\mathrm{CH}_{3}\right)$ \\
\hline
\end{tabular}


Table 2. Comparison between the observed and calculated wavenumbers $\left(\mathrm{cm}^{-1}\right)$ of vibrational spectra of $\mathrm{NEt} \mathrm{Br}_{4}$

\begin{tabular}{|c|c|c|c|c|c|c|c|c|c|c|}
\hline \multicolumn{3}{|c|}{ RHF } & \multicolumn{2}{|c|}{ DFT } & \multicolumn{2}{|c|}{ MP2 } & \multirow[t]{2}{*}{ Symm. } & \multicolumn{2}{|c|}{ Exp. } & \multirow{2}{*}{$\begin{array}{l}\text { Mode } \\
\text { Assignment }\end{array}$} \\
\hline $\mathrm{cm}^{-1}$ & $\mathrm{I}_{\mathrm{IR}}$ & $\mathrm{I}_{\mathrm{RA}}$ & $\mathrm{cm}^{-1}$ & $\mathrm{I}_{\mathrm{IR}^{*}}$ & $\mathrm{~cm}^{-1}$ & $\mathrm{I}_{\mathrm{IR}}$ & & $\operatorname{IR}(s)$ & $\mathrm{R}(\mathrm{s})$ & \\
\hline 846 & 1.22 & 3.4 & 777 & 43 & 782 & 0.76 & $\mathrm{E}$ & 802 & 789 & $v(\mathrm{~N}-\mathrm{C})+\rho(\mathrm{HCH})\left(\mathrm{CH}_{2}+\mathrm{CH}_{3}\right)$ \\
\hline 846 & 1.22 & 3.4 & 777 & 43 & 782 & 0.76 & $\mathrm{E}$ & & & $v(\mathrm{~N}-\mathrm{C})+\rho(\mathrm{HCH})\left(\mathrm{CH}_{2}+\mathrm{CH}_{3}\right)$ \\
\hline 711 & 0.00 & 12.3 & 662 & 0 & 654 & 0.00 & $\mathrm{~A}_{1}$ & & 679 & $v(\mathrm{~N}-\mathrm{C})+\sigma(\mathrm{CCN})+\omega(\mathrm{HCH})$ \\
\hline 564 & 0.00 & 0.2 & 532 & 0 & 525 & 0.01 & $\mathrm{E}$ & & & $\sigma(\mathrm{CCN})+\rho(\mathrm{HCH})$ \\
\hline 564 & 0.00 & 0.2 & 532 & 0 & 525 & 0.01 & $\mathrm{E}$ & & & $\sigma(\mathrm{CCN})+\rho(\mathrm{HCH})$ \\
\hline 441 & 0.03 & 5.2 & 414 & 1 & 420 & 0.03 & $\mathrm{~B}_{2}$ & 476 & & $\sigma(\mathrm{CCN})$ \\
\hline 433 & 0.00 & 9.9 & 406 & 0 & 407 & 0.00 & $\mathrm{~A}_{1}$ & 421 & 422 & $\sigma(\mathrm{CCN})$ \\
\hline 394 & 0.00 & 0.0 & 369 & 0 & 370 & 0.00 & $\mathrm{E}$ & 390 & & $\rho(\mathrm{CNC})$ \\
\hline 394 & 0.00 & 0.0 & 369 & 0 & 370 & 0.00 & $\mathrm{E}$ & & & $\rho(\mathrm{CNC})$ \\
\hline 377 & 0.00 & 0.6 & 356 & 0 & 360 & 0.00 & $\mathrm{~B}_{1}$ & & 370 & $\tau(\mathrm{CNC})$ \\
\hline 364 & 0.00 & 0.0 & 352 & 0 & 337 & 0.00 & $\mathrm{~A}_{2}$ & & & $\phi(\mathrm{C}-\mathrm{C})$ \\
\hline 311 & 0.00 & 0.1 & 298 & 0 & 288 & 0.00 & $\mathrm{~B}_{2}$ & & & $\rho(\mathrm{CCN})+\rho(\mathrm{HCH})$ \\
\hline 254 & 0.00 & 0.0 & 270 & 0 & 237 & 0.00 & $\mathrm{~B}_{1}$ & & & $\phi\left(\mathrm{CH}_{3}\right)$ \\
\hline 254 & 0.00 & 0.1 & 267 & 0 & 237 & 0.00 & $\mathrm{E}$ & & & $\phi\left(\mathrm{CH}_{3}\right)$ \\
\hline 254 & 0.00 & 0.1 & 267 & 0 & 237 & 0.00 & $\mathrm{E}$ & & & $\phi\left(\mathrm{CH}_{3}\right)$ \\
\hline 204 & 0.00 & 0.2 & 196 & 0 & 191 & 0.00 & $\mathrm{~A}_{1}$ & & 212 & $\sigma(\mathrm{CCN})$ \\
\hline 121 & 0.00 & 0.0 & 129 & 0 & 114 & 0.00 & $\mathrm{~A}_{2}$ & & & $\phi(\mathrm{C}-\mathrm{C})$ \\
\hline 110 & 0.02 & 0.0 & 106 & 1 & 103 & 0.01 & $\mathrm{E}$ & & & $\sigma(\mathrm{CCN})$ \\
\hline 110 & 0.02 & 0.0 & 106 & 1 & 103 & 0.01 & $\mathrm{E}$ & & & $\sigma(\mathrm{CCN})$ \\
\hline 75 & 0.00 & 0.2 & 75 & 0 & 59 & 0.00 & $\mathrm{~B}_{1}$ & & & $\phi(\mathrm{C}-\mathrm{N})$ \\
\hline
\end{tabular}

${ }^{a}$ Calculated infrared intensities $\left(I_{I R}\right)$ are in Debye ${ }^{2}\left(\AA^{-2}-A M U\right)$. Raman scattering activities $\left(I_{R A}\right)$ are in $\AA^{4} A M U^{-1}$. Calculated infrared intensities $\left(\mathrm{I}_{\mathrm{IR}^{*}}\right)$ are in $\mathrm{KMmol}^{-1}$. 